Roman Witold Ingarden i uczestnicy jego seminarium

\title{
Protokoły z posiedzeń seminarium filozoficznego wyższego Romana Witolda Ingardena (rok akademicki 1937/1938)
}

Protokół I: posiedzenie 7 października 1937 roku [protokołował Władysław Bednarowski]

Pan profesor Ingarden oznacza program pracy na rok bieżący, a następnie poszczególnym uczestnikom wyznacza funkcje, jak:

1) streszczenie jednej z sześciu ksiąg Metafizyki;

2) porównywanie różnych wydań oryginalnych tekstów Metafizyki;

3) porównywanie tłumaczeń;

4) zdawanie sprawy z komentarzy do Metafizyki Arystotelesa.

Następnie pan doktor Swieżawski wygłosił odczyt pt. „Budowa Metafizyki Arystotelesa w świetle badań Jaegera, Bonitza, Rossa".

Protokół II: posiedzenie 14 października 1937 roku [protokołował Władysław Bednarowski]

Pan Zieliński referuje pierwszą księgę Metafizyki.

Pan profesor Ingarden: Tu mamy trzy kwestie:

I. systematyczna próba określenia tej nauki;

II. przegląd dotychczasowych poglądów filozofii dotyczących czterech przyczyn;

III. krytyka tych poglądów. 
Protokół III: posiedzenie 21 października 1937 roku [protokołował Władysław Bednarowski]

Rozpoczyna się czytanie Metafizyki księgi Z.

Pan profesor Ingarden: Tò óv = słowo „byt”. Ile jest znaczeń słowa

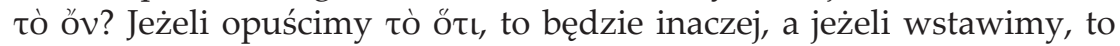
będziemy mieli trzy:

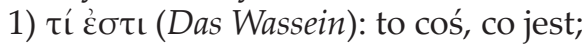

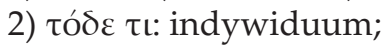

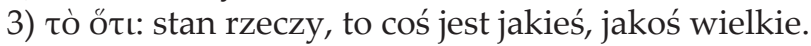

Jeżeli wyrzucimy ótı, to będziemy mieli ,jaki”, ,jak wielki” i inne tego rodzaju. Ale teraz nie rozumiem oú $\tau \omega$.

Pan doktor Swieżawski wskazuje, że Aleksander z Afrodyzji opuścił őtı1.

Pan Zawadowski twierdzi, że jest historycznie nieusprawiedliwione uważanie, że Arystoteles świadomie mówi o stanach rzeczy.

Pani doktor Gromska przytacza szereg zdań z innego miejsca tekstu, co wskazuje na prawdopodobieństwo, że Arystoteles jednak mówił o stanach rzeczy.

Protokół IV: posiedzenie 25 listopada 1937 roku [protokołował Władysław Bednarowski]

Pan profesor Ingarden wysuwa pytanie, jak należy rozumieć to $\tau i ́$

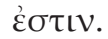

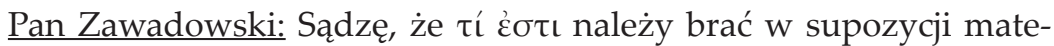

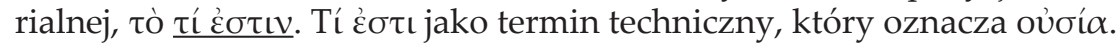

Pan profesor Ingarden: Ja też jestem za tą interpretacją. Czy tu wolno

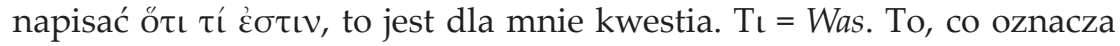

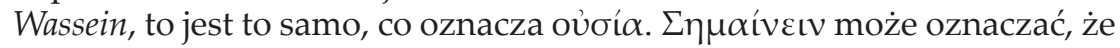

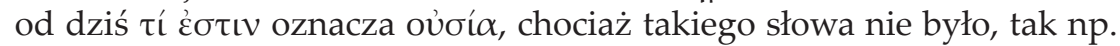
jak umawiamy się, że „lilimimi” [sic!] oznacza oủ $\sigma i ́ \alpha$. Ale tu jest inaczej: znaczenie tego słówka jest takie, że oznacza oủó́ $\alpha$.

Pan doktor Swieżawski: Św. Tomasz (1247) mówi:

Primo proponit intentum quod ens dicitur multipliciter ... quia quoddam ens significat "quid est" et "hoc aliquid", id est substantiam; ut per quid, intelligatur essentia substantiae, per hoc aliquid suppositum, ad quae duo omnes modi substantiae reducuntur ${ }^{2}$.

1 Aristotle's Metaphysics, ed. by William D. Ross, vol. 2 (Oxford: Oxford University Press, 1924), ad 1028 12 (aparat krytyczny).

2 Sancti Thomae Aquinatis, Ord. Praed., In Metaphysicam Aristotelis commentaria, cura et studio P. Fr. M. R. Cathala, 2. ed., Marietti, Taurini, 1926, 375. 
Ale wtedy wedle pana profesora tylko $\tau$ í $\dot{\sigma} \sigma \tau \iota$ byłoby substancją a $\tau o ́ \delta \varepsilon \tau \iota$ nie.

Pan profesor Ingarden: Więc wedle Tomasza oủoía jest ujęta raz poprzez esencję, a drugi raz poprzez útoké́

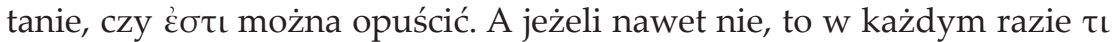
wysunęłoby się na czoło.

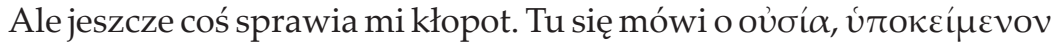
w sposób ogólny. Natomiast przy interpretacji Tomasza myśli się o tej

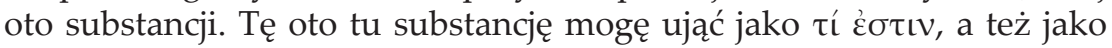
podmiot swoich cech.

Pan Zieliński:

[Wypowiedź nie została zanotowana ${ }^{3}$.]

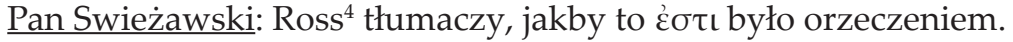

Pan Zawadowski: Mnie się zdaje, że tu trzeba położyć raczej nacisk na $\dot{\varepsilon} \sigma \tau \iota v$, bo tu chodzi o bytowość. Pan profesor zwracał uwagę na prze-

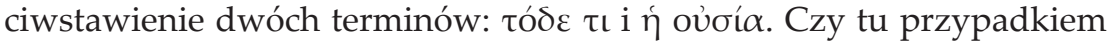

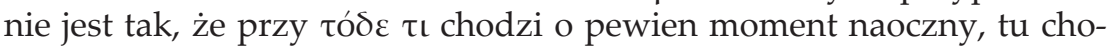
dzi o przedmiot w jego przestrzennej, naocznej postaci. Natomiast przy oủoía chodzi o pojęcie.

Pan profesor Ingarden: Istotnie, mówiąc o czymś jako oủoí $\alpha$, pojęcie

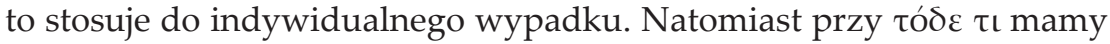
próbę pozapojęciowego wskazania: jest to jakby usamodzielniony z nazwy wskaźnik kierunkowy.

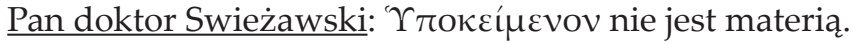

Pan profesor Ingarden: Ale stąd w konsekwencji dochodzi się do Arystotelesowskiej materii. Ale jako podmiot cech można je też tłuma-

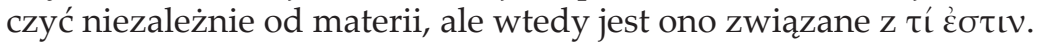

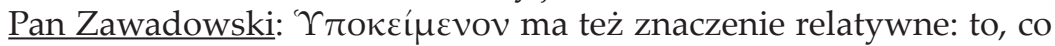
jest podłożem dla czegoś.

\section{Protokół V: posiedzenie 13 stycznia 1938 roku}

[protokołowała Izydora Dąmbska]

Ponownie przetłumaczono trzy pierwsze zdania księgi Z.

Nawiązując do dyskusji z 21 października 1937 roku pani doktor Gromska zwraca uwagę na inne miejsca Metafizyki (1089 a 6), w których

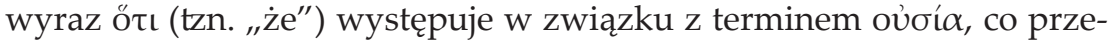
mawiałoby przeciw tendencji opuszczania analogicznego ő $\tau \iota \mathrm{w}$ pierwszych zdaniach księgi Z.

${ }^{3}$ Protokolant pozostawił cztery puste wersy na późniejsze uzupełnienie tekstu. Luka nie została jednak wypełniona.

4 The Works of Aristotle, vol. 8: Metaphysica, transl. by William D. Ross (Oxford: Oxford University Press, 1908), ad 1028. 
Pan doktor Swieżawski zaznacza, że owo o̊tı, wskazane przez panią doktor Gromska, w wydaniu Rossa wzięte jest w klamry jako wtręt interpolatora ${ }^{5}$, co osłabia siła argumentu.

Z kolei zastanawiano się, jak tłumaczyć termin oủoía:

Pan profesor Ingarden proponuje termin ,,jestestwo" jako bliski znaczeniowo znaczeniem językowym, a nie obciążony znaczeniami takimi jak wyraz „substancja”.

Pan Zawadowski dopatruje się w znaczeniu słowa „jestestwo" momentu jakości.

Pan Jaworski sądzi, że sens tego wyrazu wiąże się jakoś z pojęciem świadomości, co przybywałoby przeciw posługiwaniu się tym terminem dla oddania oủó́ $\alpha$.

Pan doktor Swieżawski proponuje, by na razie zachować termin grecki.

Następnie omawiano koniekturę Rossa 1028 a 226, czy zachować

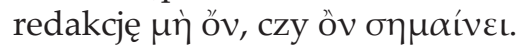

Pan profesor Ingarden sądzi, że przyjęcie tej czy tamtej redakcji nie odgrywa dla sensu całego zdania większej roli. Na redakcji drugiej mogłoby zależeć komuś, kto by poglądy Arystotelesa dotyczące kategorii chciał interpretować w duchu semantycznym.

W związku z dalszym tłumaczeniem tekstu, mianowicie zdania 1028a 20-23, rozpatrywano trzy kwestie interpretacyjne:

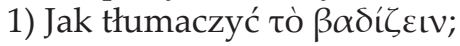

2) Jak tłumaczyć $\varepsilon$ Ǐ $\pi \varepsilon Q$;

3) Jak tłumaczyć тò $\beta \alpha \delta$ í̧ov.

ad. 1)

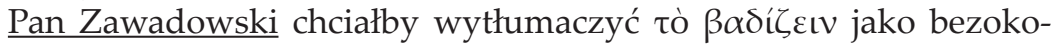
licznik.

Pani doktor Gromska zwraca uwagę, że jest to niewątpliwie substantivum verbale. Jednoznacznie rozstrzyga to zarówno składnia grecka, jak i intencja tekstu. Dopiero bowiem przy rzeczownikowym znaczeniu tego słowa usprawiedliwione jest występujące na początku zdania wyrażenie $\dot{\alpha} \pi 0 \varrho \eta ́ \sigma \varepsilon เ \varepsilon$. Gdyby szło o czasownik, nie nasuwałaby się żadna wątpliwość w rozstrzyganiu, o jaką kategorię chodzi.

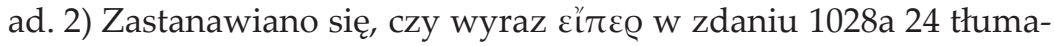
czyć przez „jeżeli już", resp. ,jeżeli w ogóle”, czy też przez „w wyższym stopniu". Tę drugą interpretację wysunął pan profesor Ingarden i pani doktorka Romahnowa. Przeciw tej interpretacji wypowiedziała się pani doktorka Gromska, przypominając znaczenie właściwe słowa عĭre@.

5 Aristotle's Metaphysics, ad $1028^{a} 12$ (aparat krytyczny).

6 Tamże, ad 1028 21 (aparat krytyczny). 
ad. 3) W związku z wyrażeniem tò $\beta \alpha \delta i \zeta \zeta o v$ pan profesor Ingarden proponuje, by tłumaczyć je przez "to chodzące" raczej aniżeli przez „to, co chodzi”, aby uwydatnić w ten sposób całościowe ujmowanie tego przedmiotu. W znaczeniu bowiem zwrotu „to, co chodzi", jest pewne przeciwstawienie substratu i spełnianej przez niego funkcji. Tu zaś chodzi o całość substancjalną.

Protokół VI: posiedzenie 27 stycznia 1938 roku

[protokołował Władysław Bednarowski]

Tłumaczenie zdania 1028a 25-27.

Pan Zawadowski: „A te raczej wydają się bytami, dlatego że jest coś,

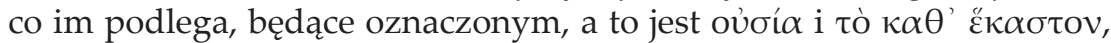
co ujawnia się w tym orzeczniku".

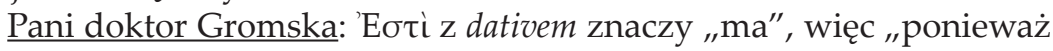

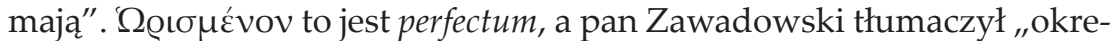
ślane”. Więc: „ponieważ mają jakieś określone podłoże (podścielisko)”.

Pan Zawadowski: „Podłoże” może oznaczać materię Arystotelesa, a ja umyślnie użyłem szerzej.

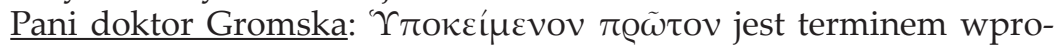
wadzonym już w poprzednich księgach.

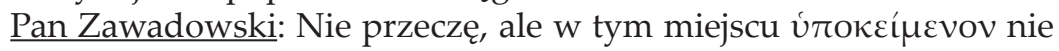
ma znaczenia podłoża jako materii.

Pan profesor Ingarden: Może więc pan Zawadowski zobaczy $\mathrm{w}$ indeksie, a potem nam zreferuje? A na razie może utrzymamy termin „podłoże".

Pan doktor Swieżawski: Nie rozumiem dokładnie tego zdania. Czy $\tau \alpha \tilde{v} \tau \alpha$ przeciwstawia się $\beta \alpha \delta i ́ \zeta \varepsilon เ v ?$

Pan profesor Ingarden: Tak to siedzące ma jakieś określone podłoże.

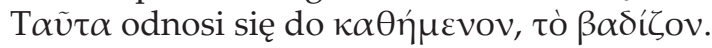

Drugie zadanie:

Pani doktor Gromska: " przedmiot indywidualny.

Pan profesor Ingarden: To, co się odnosi do każdego, co się o każdym poszczególnym z pewnej klasy [twierdzi]. Pierwsza trudność w tym, że musimy dodać „poszczególnym”. Druga trudność: to, do czego się od-

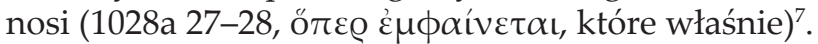

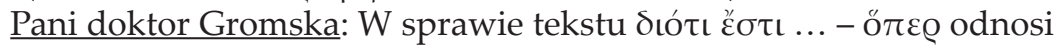

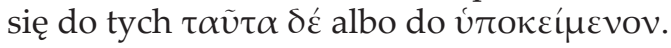

7 Protokolant $\mathrm{w}$ tym miejscu zanotował jedynie hasłowo drugą trudność, pozostawiając niemal całe trzy puste wiersze na późniejsze uzupełnienie tekstu. Brakującego tekstu jednak nie uzupełniono. 
Pan doktor Swieżawski: Tak jest to u Rossa ${ }^{8}$, tylko że Ross nie podaje wytłumaczenia dla tej interpretacji.

Dalszy ciąg tłumaczenia: „te wydają się bardziej realnymi, ponieważ istnieje coś określonego, co służy im jako podłoże, tzn. substancja lub coś indywidualnego, co zawiera się w takim orzekaniu".

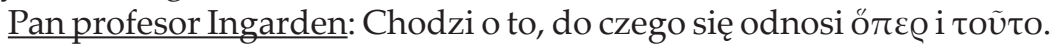

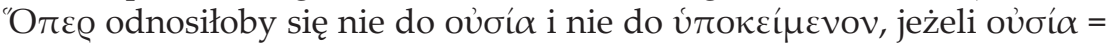

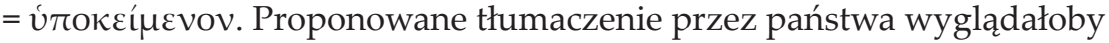
tak: „,to coś jest substancją lub coś indywidualnego, podłoże, które przejawia się w tym odpowiednim zdaniu".

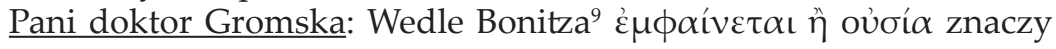
podłoże, w którym tkwi implicite substancja.

Pan profesor Ingarden: To by znaczyło, że jeżeli orzekam o czymś,

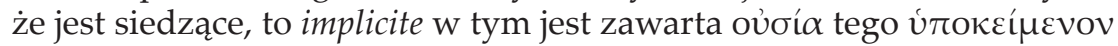
$\kappa \alpha \theta^{\prime} \varepsilon \check{\kappa} \kappa \alpha \sigma \tau o v$. To bez tego nie da się powiedzieć. Ja odróżniam w nazwie treść formalną i materialną. Na przykład formalna treść nazwy "pies" oznacza mi przedmiot ucechowany, rzecz. Natomiast "biegł" oznacza mi proces. Więc może o coś podobnego tutaj chodzi. Jeżeli mówię "dobry”, to w tym jest zawarte to coś, co jest dobre. Ale można też rozumieć inaczej: dobroć musi być dobrocią czegoś.

Pan Zawadowski tłumaczy dalej: „te zaś wydają się być bytami, bo mają pewne określone podłoże. A nim jest oủoía i coś jednostkowego".

Pani doktor Gromska: Lasson ${ }^{10}$ mówi zamiast „i" - „a mianowicie”. Można by może tłumaczyć ",czy”.

Pan Zawadowski: „,i (lub, a mianowicie) to, co jednostkowe, które to podłoże przejawia się $\mathrm{w}$ takim orzeczniku. To dobre bowiem lub to siedzące nie mówi się bez tego".

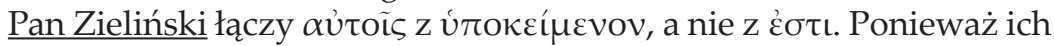
podłożem jest coś określonego. Ponieważ istnieje coś, co jest ich określonym podłożem.

Pan profesor Ingarden: Ale to na jedno wychodzi.

Pani doktor Dambska: To nie musi być to samo. Na przykład przy nazwie prostej: to coś ma swoje podłoże, ale nie istnieje podłoże.

Pan profesor Ingarden: Tak, byłaby to różnica między twierdzeniem ontologicznym a metafizycznym.

Pan doktor Swieżawski: Tomasz daje pewne wyjaśnienie na temat

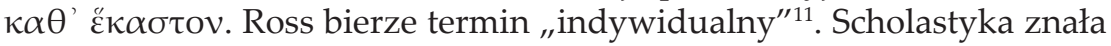

8 The Works of Aristotle, ad 1028.

9 Aristotelis Metaphysica, recogn. H. Bonitz, p. 2, Ad. Marcus (Bonnae, 1849), 295.

10 Aristoteles, Metaphysik, übers. von A. Lasson (Jena: Eugen Diederichs, 1907), 93.

11 The Works of Aristotle, ad $1028^{\mathrm{a}}$. 
termin „konkretny”. Komentarz Tomasza (1255) „inquantum significantur ... concretum substantiae ${ }^{\prime 12}$ być może mógłby to wyjaśnić.

Pan profesor Ingarden: Czy $\kappa \alpha \theta^{\prime} \varepsilon \check{\kappa} \kappa \alpha \sigma \tau o v$ nie można tłumaczyć „,to, co pod każdym względem jest jakieś" - a to znaczy indywiduum.

Pan Zawadowski: Tomasz mówi o accidentiach, że niektóre z nich są in abstracto, a niektóre in concretione (na przykład sedens, sanans) ${ }^{13}$. A abstrakcyjne byłyby $\beta \alpha \delta i \zeta \varepsilon \iota v, \kappa \alpha \theta \tilde{\eta} \sigma \theta \alpha \mathrm{t}$.

Pan profesor Ingarden: Więc bezokolicznik to byłby ogólnik. Ale można rozumieć jeszcze inaczej: jeżeli mam „białość", to to jest coś, co nie jest niczemu przypisane. Natomiast przy „białym” mamy treść formalną przysługującą jakiemuś przedmiotowi.

Przekład zdania 1028a 29-30.

Pan Kohlmann: „Jasne więc, że z powodu oủoí $\alpha$ każde (z tych) jest z owego (czy z tych)".

Pan profesor Ingarden: "Jasne, że dzięki tej oủoía istnieje każde z owych".

Pan Kohlmann: „Tak, że pierwszym bytem i że co nie jest coś”.

Pani doktor Gromska: „Tak, że to, co istnieje w sposób pierwszy i co nie jest czymś, ale po prostu jest substancją".

Pan doktor Swieżawski: Spotkałem się z rozróżnieniem, że jest jedna kategoria substancji i dziewięć akcydentalnych.

Pani doktor Dambska: Bender ${ }^{14}$ tłumaczy zgodnie z tym, co mówił pan Swieżawski.

Pan profesor Ingarden: Byłbym skłonny do przyjęcia, że to po prostu istniejące jest oủoía.

Pani doktor Gromska: A $\pi \lambda \tilde{\omega} \varsigma$ dosłownie znaczy "po prostu”, ale u Arystotelesa "we właściwym znaczeniu”.

Pan doktor Swieżawski: To dotyka jednego z rozróżnień podstawowych w scholastyce: ens simpliciter i ens aliquid ${ }^{15}$. Bycie białym nie jest esse simpliciter, lecz secundum quid.

Protokół VII: posiedzenie 3 lutego 1938 roku

[protokołowała Halina Korczyńska]

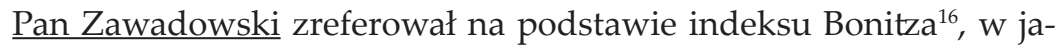

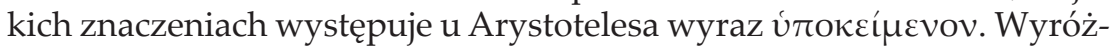
nił on trzy grupy znaczeń tego wyrazu:

12 Sancti Thomae Aquinatis, 376.

13 Tamże, s. 376.

14 Die Metaphysik des Aristoteles, übers. von H. Bender (Stuttgart: Hoffmann'sche Verlags-Buchhandlung [b. d. w.]), 164.

15 Sancti Thomae Aquinatis, 373, 375.

16 Aristotelis Metaphysica, 622. 


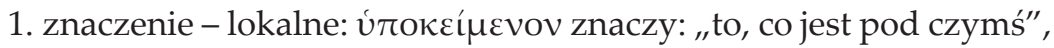
„to, co służy czemuś za podstawę";

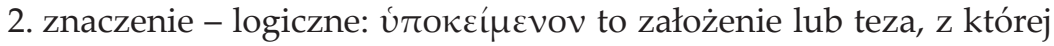
wynikają jakieś wnioski;

3. grupa znaczeniowa rozpada się z kolei na trzy dalsze rodzaje:

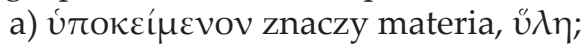

b) oủoía, której przysługują stany, cechy;

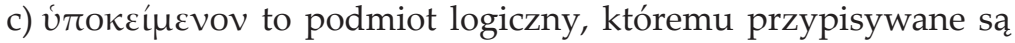
orzeczniki.

Wyraz útokєí $\mu \varepsilon v o v$ nie jest zatem jednoznaczny. Zgodnie z intencją Arystotelesa należy go w różnych miejscach tłumaczyć rozmaicie.

Pani doktor Gromska na pytanie, czy mamy prawo tłumaczyć tò $\kappa \alpha \theta^{\prime}$ ह̌ $\kappa \alpha \sigma \tau o v$ jako "przedmiot indywidualny", odpowiada na podsta-

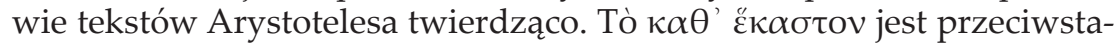

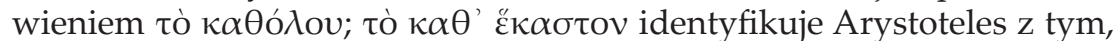
co numerycznie jedno. Pani doktor Gromska przytacza między inny-

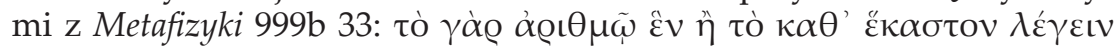

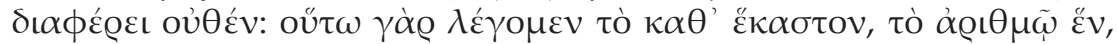

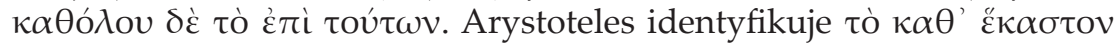
również z tym, co dane w doświadczeniu, co jest spostrzeżone.

Pan profesor Ingarden zgadza się, że wolno i należy $\kappa \alpha \theta^{\prime}$ ह̌ $\kappa \alpha \sigma \tau o v$ tłumaczyć jako „przedmiot indywidualny”, jednak kontrastowanie z $\kappa \alpha \theta$ ó ov nie wyjaśnia, jak się do tego doszło.

K $\alpha \theta$ ódov można interpretować dwojako:

1) to, co się orzeka o poszczególnych, ale wszystkich przedmiotach pewnej klasy, cechy powtarzające się;

2) jakość ogólna.

W przeciwstawieniu do pierwszej interpretacji $\kappa \alpha \theta$ ó $\lambda$ ov $-\kappa \alpha \theta$

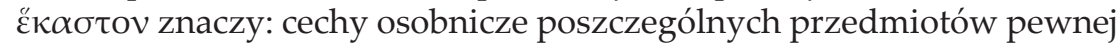
klasy. Znaczenia "przedmiot indywidualny" z tego przeciwstawienia nie dostaję.

Pan doktor Swieżawski: W późniejszych interpretacjach esse cechy osobniczej i esse przedmiotu - to jedno i to samo.

Pan doktor Bednarowski: Tò $\kappa \alpha \theta^{\prime}$ Ěk $\alpha \sigma \tau o v$ wiąże się z nazywa-

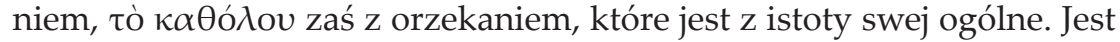
to przeciwstawienie $\mathrm{z}$ uwagi na budowę zdania.

Pan profesor Ingarden: To byłaby interpretacja semantyczna, jednak $\mathrm{w}$ tekście $\mathrm{w}$ obu wypadkach jest $\lambda \dot{\gamma} \gamma \omega$.

Pani doktor Gromska: Tò $\kappa \alpha \theta^{\prime}$ Ék $\alpha \sigma \tau o v$ pokrywa się z tym, co spostrzegane.

Pan profesor Ingarden: To, co spostrzegam, może być dwojako rozumiane:

1) jako egzemplarz;

2) jako indywiduum (Bergson). 


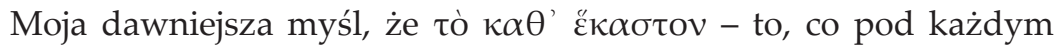
względem - była nietrafna.

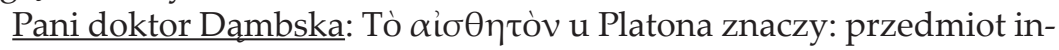
dywidualny.

Pan Zawadowski uważa, że nie należy mówić, że u Arystotelesa cecha osobnicza i przedmiot indywidualny zostały pomieszane. To jest rozróżnienie późniejsze, u Arystotelesa go jeszcze nie było. To nie jest błąd, lecz konieczna faza historyczna.

Pan profesor Ingarden: Rozróżnienia tego nie było w sensie intencjonalnych korelatów Arystotelesa, ale rzeczowo różnica była zawsze.

Następnie przystąpiono do tłumaczenia 1028a 31 i następne.

Są tu różnice tekstów: 1) w pewnych redakcjach nie ma słów: кaì

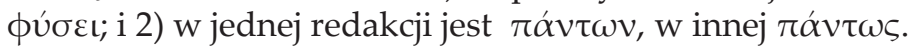

Pan profesor Ingarden: Пáv $v \tau \omega \varsigma$ odnosiłoby się do $\lambda o ́ \gamma \omega, \gamma \nu \omega ́ \sigma \varepsilon$,

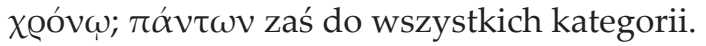

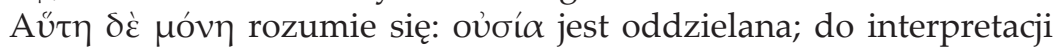
tego miejsca wrócimy przy czytaniu caput trzeciego.

\section{Protokół VIII: posiedzenie 10 lutego 1938 roku [protokołowała Izydora Dąmbska]} gi Z.

Pan doktor Swieżawski tłumaczy koniec pierwszego rozdziału księ-

Pan profesor Ingarden: Oủoía w tym miejscu jest rozważana pod aspektem poznania. Tłumaczenie Lisieckiego odbiega znacznie od tłumaczenia pana doktora Swieżawskiego, który zbliża się raczej do tłuma-

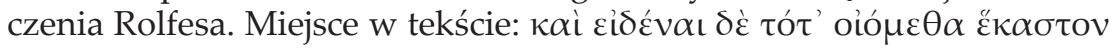

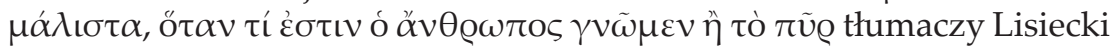
następująco: „A odnośnie do jakiegokolwiek bytu sądzimy, że znamy go tylko wtenczas, gdy wiemy, że to człowiek, a to ogień" ${ }^{17}$.

17 Grupa seminaryjna korzystała z egzemplarza tłumaczenia Metafizyki Arystotelesa, autorstwa Stanisława Lisieckiego. Egzemplarzem przygotowanym do druku dysponował Roman Witold Ingarden. W korespondencji z Konstantym Michalskim zachowały się jego uwagi dotyczące tego tekstu (Archiwum Nauki PAN i PAU w Krakowie, sygn. rkps. K-III 26: Roman Ingarden, j. 84, 11). Tekst tłumaczenia Lisieckiego oraz fragment jego korespondencji z Romanem Witoldem Ingardenem zachowały się w: Polska Akademia Nauk. Archiwum w Warszawie, sygn. rkps. III-14: Stanisław Lisiecki, przekłady dziełPlatona i Arystotelesa: zob. Zygmunt Kolankowski, „Przegląd zawartości zbiorów i kolekcji działu «Spuścizn» Archiwum PAN", Kwartalnik Historii Nauki i Techniki 1, R. 1 (1956): 473. Osoba Stanisława Lisieckiego jest przypominana dzięki działalności naukowej Tomasza Mroza (zob. m.in. Tomasz Mróz, Platon w Polsce, 280-303; tegoż, Zapomniany historyk filozofii starożytnej: Stanisław Lisiecki (1872-1960), 157-177 oraz tegoż, Polish Studies on Plato under the Oppression of Censorship: Lutoslawski - Lisiecki - Witwicki, 137-148). 
Pan profesor [Ingarden] odczytuje dalej tłumaczenie Rolfesa: „Und das beste Wissen von jedem schreiben wir uns dann zu, wenn wir erkannt haben, was der Mensch oder das Feuer ist"18. Z innych tłumaczeń tłumaczenie Lassona ${ }^{19}$ jest zbliżone do Lisieckiego. Tu wyłania się kwestia, czy wyraz ó äv $\theta \varrho \omega \pi$ o jest tu wzięty w sensie generalnym, czy w sensie egzemplarza dowolnego, co do którego pytamy się dalej, co on jest, resp. kto on jest, na przykład, że to właśnie Mickiewicz. Jeśli powiemy, co jest ten człowiek, to narzuca się myśl, że indywiduum jest brane tu sub specie generalnej nazwy.

Pan doktor Swieżawski: W tłumaczeniu świętego Tomasza z Akwinu jest "quid est homo" ${ }^{20}$. „Homo" więc jest tu wzięte w znaczeniu generalnym. Podobnie jest $\mathrm{u}$ Rossa ${ }^{21}$. Natomiast $\mathrm{u}$ Bonitza jest nazwa Mensch poprzedzona rodzajnikiem (der Mensch) ${ }^{22}$.

Pan profesor Ingarden sądzi, że tłumaczenie Lisieckiego jest najdalsze od tekstu. W tekście nie ma tego "to" (w wyrażeniu: „że to człowiek"). Pan profesor godzi się na to, że są motywy, które by inspirowały takie thumaczenie tego miejsca. Nie wynikają one jednak z tekstu.

Pani doktor Gromska: Tekst wskazywałby na tłumaczenie Bonitza. W języku niemieckim sytuacja jest jasna. Bonitz tłumaczy ó przez rodzajnik określony, a nie nieokreślony ${ }^{23}$. W tym ostatnim wypadku musiałoby ó być opuszczone.

Pan profesor [Ingarden] formułuje trzy możliwe wypadki tłumaczenia tego miejsca w języku niemieckim: 1) Was ist ein Mensch?; 2) Wer ist der Mensch?; 3) Wer ist dieser Mensch?

Pani doktor Gromska sądzi, że ten trzeci wypadek w ogóle nie może zachodzić.

Pan profesor [Ingarden] sądzi, że ten tekst jest w sposób widoczny pod wpływem Platona. Pierwszy wypadek byłby zgodny z Arystotele-

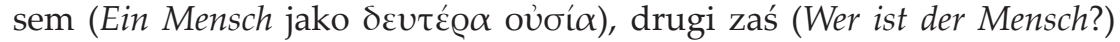
wskazuje na platońską interpretację. Tu bowiem eksplikuje się gatunek. Trzeci wypadek miałby znów charakter arystotelesowski. To wszystko jest w związku z wieloznacznością nazwy oủoía. Nazwa ta jest w drugim rozdziale wzięta generalnie, a więc po platońsku. Podobnie sprawa

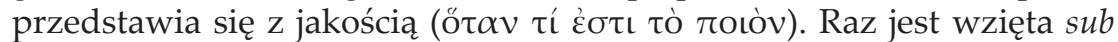

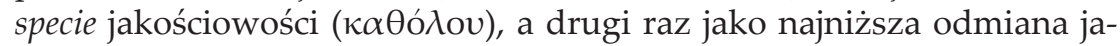
kości (ta oto tu jakość).

18 Aristoteles' Metaphysik, übers. von E. Rolfes, 2., verbesserte Aufl., Erste Hälfte: Buch I-VII (Leipzig: Verlag von Felix Meiner, 1920), 131.

19 Aristoteles, Metaphysik, übers. von A. Lasson, 94.

20 Sancti Thomae Aquinatis, 390.

21 The Works of Aristotle, ad 1028.

${ }_{22}$ Aristoteles, Metaphysik, übers. von H. Bonitz, aus dem Nachlass hrsg. von E. Wellmann, Georg Reimer (Berlin 1890), 128.

23 Tamże. 
Pan doktor Swieżawski przedstawia swoje wątpliwości: $1^{\circ} \mathrm{Czy}$ wolno wprowadzać naświetlenia, których nie ma jeszcze w lekturze?; $2^{\circ} \mathrm{Czy}$

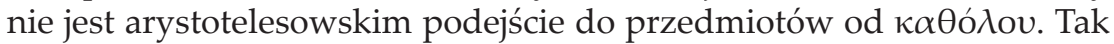
przynajmniej Arystotelesa scholastyka rozumiała. To quid est odnosi się do poznania od strony formalnej, gatunkowej, a nie indywidualnej. Więc zgodnym z Arystotelesem byłoby pytanie: „Co to jest człowiek?”.

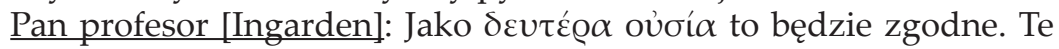

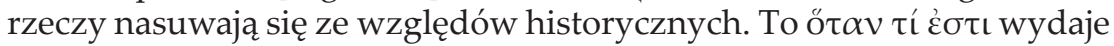
się też więcej platońskim niż arystotelesowskim.

Pan Zawadowski zapytuje, czy istotnie należy tłumaczyć „,wielkość” czy , ,jakość", czy nie lepiej by było tłumaczyć przez "tak wielkie” lub bądź takie: „to, co jest jakoś wielkie”. Następnie cytuje komentarz Świętego Tomasza z Akwinu, z którego wynika, że on rozumie qualitas jako

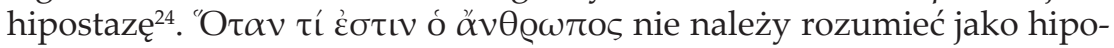
stazy. Tu mamy do czynienia z definicją człowieka. Jednostkowe rzeczy mogę też poznawać jako ogólne.

Pan profesor [Ingarden]: Jeśli definicja człowieka według Pana eks-

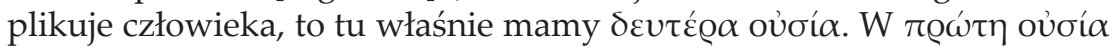
chodzi o coś zupełnie innego.

Pani doktor Gromska sądzi że tu nie chodzi o definicję człowieka,

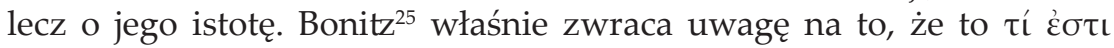
dotyczy istoty rzeczy (Wesen), w przeciwstawieniu do oủ $\sigma i ́ \alpha$. Raz idzie o substancję jako jedną z dziesięciu kategorii, a drugi raz o istotę. Co do tłumaczenia przez pana Zawadowskiego tò roı̀v przez "to, co jest jakoś wielkie", a nie w znaczeniu wielkości, to z tekstu, zdaje się, dość

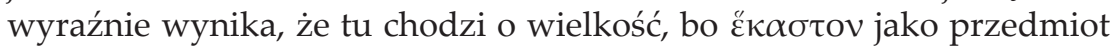
gramatyczny na to wskazuje.

Pan doktor Bednarowski popiera twierdzenie pani doktor Gromskiej, że tu raczej chodzi o istotę niż substancję.

Pan doktor Swieżawski: To miejsce komentarza Świętego Tomasza z Akwinu stoi na stanowisku istoty.

Pan profesor Ingarden nie chciałby tego miejsca tłumaczyć przez „istotę", gdyż jest tu cały szereg kwestii wątpliwych, jak: czy do istoty jakieś rzeczy należy $\tau \iota$; czy każde $\tau \iota$ każdej rzeczy jest jej istota, i tak dalej.

Pani doktor Romahnowa tłumaczy dalej.

Pan Zawadowski chciałby za Bonitzem ${ }^{26} \pi \lambda \varepsilon i ́ \omega$ tłumaczyć jako

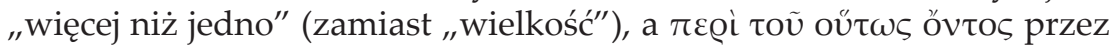
„w ten sposób istniejący".

Rozdział drugi księgi Z rozpoczęto krytyką tekstu (pan Kohlmann). Następnie zaczął tłumaczyć pan Zieliński.

24 Sancti Thomae Aquinatis, 396.

25 Aristotelis Metaphysica, 297.

${ }^{26}$ Aristoteles, Metaphysik, übers. von H. Bonitz, 128. 
Pierwszą wątpliwość nasuwa wyraz úTáoxeıv.

Pan Zieliński tłumaczy to słowo przez „przynależy” („Zdaje się, że oủoía przynależy ciałem").

Pan Jaworski tłumaczy: "Oủoía wydaje się stanowić podstawę", przy czym powołuje się na istniejące podobne słownikowe znaczenie.

Pani doktor Romahnowa tłumaczy przez „należy do ciał”.

Pani doktor Gromska sądzi, że Arystoteles podaje tu potocznie przyjęty pogląd, więc nie potrzeba biedzić się nad tłumaczeniem. Technicznie úTáoxєı znaczy ",przysługiwać”.

Pan Zawadowski: Zdaniem Świętego Tomasza z Akwinu ${ }^{27}$ jest tu postawiony nacisk na modus existentiae. Wedle Świętego Tomasza z Akwinu Arystoteles chciał przez v́Táoxeıv wyrazić myśl, że ciała istnieją $\mathrm{w}$ taki sam sposób jak substancje. Bonitz stawia útáaðعıv przy innej sposobności ${ }^{28}$ na równi z عĩv $\alpha$, które przeciwstawia $\lambda \varepsilon ́ \gamma \varepsilon \sigma \theta \alpha \mathrm{L}$. To pozwala zrozumieć stanowisko św. Tomasza z Akwinu.

Pan profesor Ingarden: W drugim rozdziale chodzi o rozmaite zakresy, pod którymi oủoí $\alpha$ występuje. Tu bywa oủoí $\alpha$ używana raz $\mathrm{w}$ szerszym, raz w węższym zakresie. Pan profesor przychyla się do stanowiska pani doktor Gromskiej, tzn. zaniechania dyskusji nad wy-

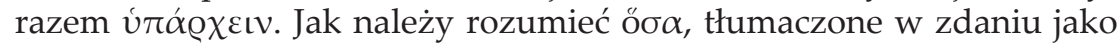
„Wszystko, co"?

Pan Zieliński sądzi, że ó $\alpha$ nie ma ilościowego charakteru.

Temu sprzeciwia się pani doktor Gromska, podkreślając wybitne cechy konstytutywne tego wyrazu.

Dalszy tekst tłumaczy pan Jaworski.

Pan Zieliński rozumie $\mu$ ovd̀ $\varsigma$ jako jednostkę pitagorejską.

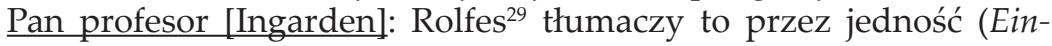
heit), co jest bliższe prawdzie.

$\Sigma \tau \varepsilon \varrho \varepsilon \dot{v}$ rozumie pani doktor Gromska jako trójwymiarowy.

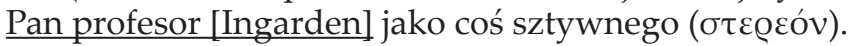

Pan Zawadowski sądzi, że to miejsce da się lepiej wytłumaczyć, gdy się wie, czyje poglądy tu są przedstawione. Chodzi tu niewątpliwie o pitagorejczyków (Filolaos może). Są to tendencje geometryzacji

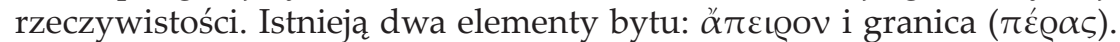
’A $\pi \varepsilon$ Lo $v$ jest u pitagorejczyków niezdeterminowaną materia, nieograniczoną rozciągle. Tę rozciągłość determinuje poznanie matematyczne przez punkt, linię, płaszczyznę, $\sigma \tilde{\omega} \mu \alpha$. $\Sigma \tilde{\omega} \mu \alpha$ nie jest tu substancja, ale pewnym ukonstytuowanym tworem o prostych składnikach.

27 Sancti Thomae Aquinatis, 396.

28 Ustalono na podstawie: Aristotelis Metaphysica, 622.

29 Aristoteles' Metaphysik, 131. 
Pan profesor [Ingarden]: Lisiecki ${ }^{30}$ tłumaczy $\sigma \tau \varepsilon \varrho \varepsilon o ́ v ~ j a k o ~ \sigma \tilde{\omega} \mu \alpha$ określone czymś, mianowicie "ciało obdarzone tężyzną".

Pan doktor Swieżawski: Tu chodzi, zdaje się, o ciało stałe.

Pani doktor Gromska cytuje miejsce z księgi B (1000 2a), z którego wynika, że $\sigma \tilde{\omega} \mu \alpha$ jest jestestwem niższego rzędu niż powierzchnia, linia, punkt.

Protokół IX: posiedzenie 17 lutego 1938 roku protokołował Bolesław Zieliński

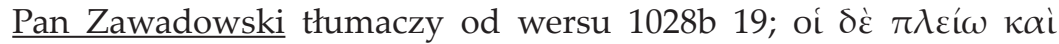

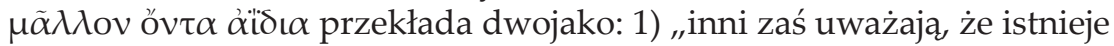
w większej ilości coś, co jest bardziej wieczne" (powołuje się na Bonit$\left.z^{31}\right)$ i 2) „,inni zaś uważaja, że jest w większej ilości i jest czymś bardziej wiecznym".

Wywiązuje się na ten temat dyskusja.

Pani doktor Gromska sądzi, że $\mu \tilde{\alpha} \lambda \lambda$ ov odnosi się do őv $\alpha$ i powołuje się na św. Tomasza.

Pan profesor Ingarden zwraca uwagę, że u Rolfesa ${ }^{32}$ jest podobne tłumaczenie.

Pan doktor Swieżawski wyraża swoje przekonanie, iż po ditioı $\alpha$ należy dodać oủoíaı.

Pan profesor Ingarden ujmuje powyższe trudności w dwa pytania -

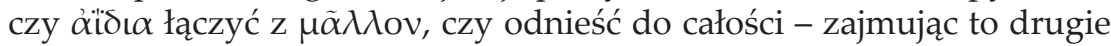

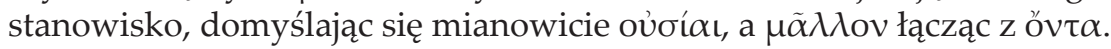

Pan Zieliński zwraca uwagę, że takie stanowisko zajmuje też Ross ${ }^{33}$.

Drugą sprawa, która wywołała dyskusję, było przetłumaczenie wersów 1028b 22, 23.

Pan doktor Swieżawski pyta się, jak powinno tłumaczyć się d̉@xদ́.

Sprawę rozstrzygnięto przez odwołanie się do księgi A.

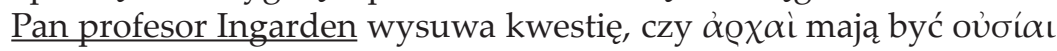
i czym w ogóle mają być.

Pani doktor Gromska cytuje odnośnie komentarz Rossa ${ }^{34}$.

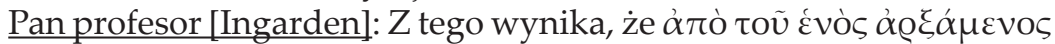

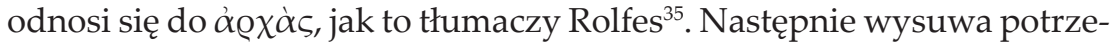
bę zaczerpnięcia wiadomości z historii matematyki.

\footnotetext{
${ }^{30}$ Zob. wcześniejszą uwagę dotyczącą tłumaczenia S. Lisieckiego.

31 Aristoteles, Metaphysik, übers. von H. Bonitz, 129.

32 Aristoteles' Metaphysik, 131.

33 The Works of Aristotle, ad 1028b

34 Aristotle's Metaphysics, 163.

${ }^{35}$ Aristoteles' Metaphysik, 132.
} 
Pani doktor Gromska zwraca uwagę na to, że Christ chciałby usunąć

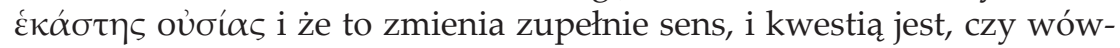
czas zdanie, w którym te słowa występuja, posiadałoby dalej sens.

W związku z tym pan profesor Ingarden wysuwa problem: 1) czy

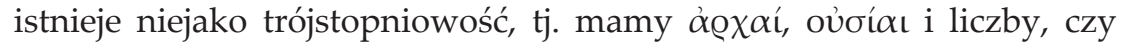
2) $\dot{\alpha} \varrho \iota \mu \tilde{\omega} v$ stoi na miejscu pewnej oủoí $\alpha$. Ponieważ wszystkie te sprawy dotyczą poglądów Speuzypa, pan profesor Ingarden zaproponował zebranie wszystkich miejsc u Arystotelesa traktujących powyższy temat. Zrobi to pan Zieliński.

Od 1028b 24 tłumaczy dalej doktor Bednarowski. Trudności zwią-

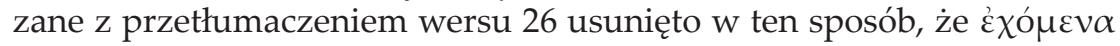
uzupełniono przez eĩval, czyli słowa te przetłumaczono następująco: „inne zaś wywodzą się (z tamtych) jak..." - po uwzględnieniu poprawki pani doktor Gromskiej, dotyczącej tłumaczenia ú (31 wers), ukończono przekład drugiego rozdziału.

Następnie pan Kohlmann zreferował krytykę filologiczną tekstu trzeciego rozdziału.

Na wniosek pana doktora Swieżawskiego postanowiono na przyszłość omawiać powyższą sprawę nie ogólnie, lecz odnośnie do poszczególnych miejsc w trakcie, gdy zajdzie tego potrzeba.

Na tym pan profesor Ingarden zamknął posiedzenie.

Protokół X: posiedzenie 24 lutego 1938 roku

[protokołował Władysław Jaworski]

Pani doktor Dambska tłumaczy caput trzecie:

Mówi się o oủóí jeśli nie więcej, to co najmniej w czterokrotnym znaczeniu. Wydaje się bowiem oủóí i tym, co coś jest, i tym, co ogólne, i rodzajem, i po czwarte podłożem tych rzeczy. Podłożem zaś jest to, o czym się wszystkie inne orzeka, podczas gdy jego samego już nie orzeka się o niczym innym. Dlatego najpierw z tego należy zdać sobie sprawę. Przede wszystkim zaś wydaje się podłoże być oủoí $\alpha$.

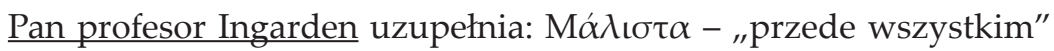
przed "co najmniej".

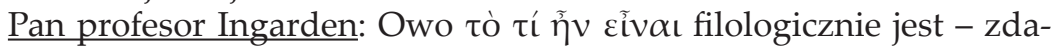
niem pani Gromskiej - zrozumiałe. Jak to się zatem tłumaczy?

Pani doktor Gromska: Postawiając zamiast imperfectum $\tilde{\eta} v-\dot{\varepsilon} \sigma \tau \iota$ wy-

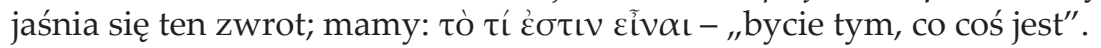

Pan profesor [Ingarden]: Zatrzymawszy to ฑ๊v, czyli „bycie czymś takim, jakim się było", dochodzimy do pewnej koncepcji. Na przykład, mając szereg faz czasowych na jakimś przedmiocie, wiem, że zachodzą one na nim, jeśli jest on identyczny. Cały materiał tego przedmiotu jest 
ten sam, lecz jego postać się zmienia (raz coś jest, na przykład grecką wazą a raz pastą do butów), ten przedmiot jednak jest ciągle tego pewnego $\tau \iota$, jakim był. On to $\tau \iota$ zachowuje. Warunkiem zachowania tożsamości - według mojej dawnej terminologii - jest zachowanie natury przedmiotu. Tu zatem szłoby o naturę przedmiotu. Biorąc rzecz prezentywnie, nie możemy dojść do tej koncepcji.

Pan doktor Swieżawski: U Tomasza jest to tłumaczone zarówno jako quod erat esse, jak i jako quod est esse.

Pan profesor [Ingarden]: Gdyby to $\tilde{\eta} v$ usunięto znaczenie perfectum, to nie byłoby to na rękę mojej koncepcji. Jeżeli zaś to jest imperfectum, to dobrze by było znać jego funkcję w greczyźnie.

Pani doktor Gromska: Do eiui nie ma perfectum i imperfectum tu objęło jego funkcję.

Pan profesor [Ingarden]: Profesor Kuryłowicz mi mówił, że gdy używam perfectum, to ujmuję to, co się stało, niejako z daleka, podczas gdy przy imperfectum cofam się do przeszłości i stamtąd ujmuję to, co uczyniłem, drugi raz to niejako współrozwijając. Mówiąc o Napoleonie, mogę go ujmować wciąż im perfektywnie, a nie na przykład w "cięciach" Whiteheadowskich. Jak zatem teraz tłumaczyć ten zwrot?

Pan doktor Swieżawski cytuje szereg określeń łacińskich: definitio, ratio formalis i inne - $\mathrm{u}$ Lassona: das begriffliche Wesen ${ }^{36}$, u Bonitza: das Wesenswas $^{37}$, u Bendera: der Begriff38, u Lisieckiego: istota, dzięki której rzecz jest tym, czym jest ${ }^{39}$, u Tomasza: quod [quid] erat esse, [idest] quidditas, [vel] essentia sive natura reit ${ }^{40}$.

Pan doktor Bednarowski proponuje nazwę „sobość".

Pan profesor [Ingarden]: Identyczność będzie przekreślona, gdy rzecz pozostaje soba, ale tu chodzi raczej o warunek niezbędny tego, że

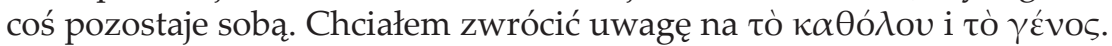

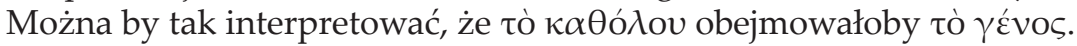

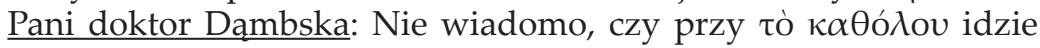
o nazwę ogółu, czy o pojęcie.

Pan profesor [Ingarden]: Szłoby o znaczenie nazwy, o to, co treść materialna nazwy wyznacza jako wspólne wszystkim egzemplarzom jakiejś klasy.

Pani doktor Gromska: Arystoteles, według Bonitza ${ }^{41}$, nie zawsze

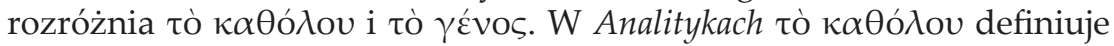
jako to, co orzeka się o całym zakresie, lub to, co przysługuje każde-

\footnotetext{
36 Aristoteles, Metaphysik, übers. von A. Lasson, 95.

37 Aristoteles, Metaphysik, übers. von H. Bonitz, 129.

38 Die Metaphysik des Aristoteles, übers. von H. Bender, 166.

39 Zob. wcześniejszą uwagę dotyczącą tłumaczenia S. Lisieckiego.

40 Sancti Thomae Aquinatis, 381.

${ }^{41}$ Aristotelis Metaphysica, 299.
} 
mu egzemplarzowi z tego zakresu. Bonitz dochodzi do wniosku, że tò

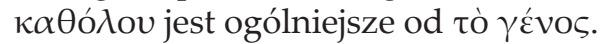

Pan profesor [Ingarden] czyta komentarz odnośny u Rolfesa ${ }^{42}$, gdzie jest mowa o substantia secunda.

Pan doktor Swieżawski: W krytyce prac o Arystotelesie Mansion ${ }^{43}$ podaje, że trzeba być ostrożnym względem rozróżnień na pierwszą i drugą substancję, co zostało później prawdopodobnie wprowadzone przez uczniów Arystotelesa w Kategoriach.

Pan Zawadowski: W Kategoriach problematyka i nastawienie jest arystotelesowskie według Jaegera ${ }^{44}$, ale mieli to spisać uczniowie i wtedy dostały się tam też późniejsze tendencje.

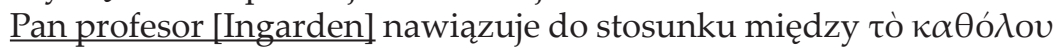

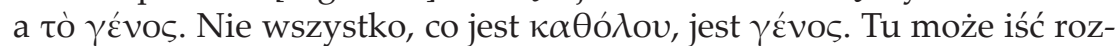
różnienie między naturą a cechami. Pewien indywidualny przedmiot, na przykład Goethe, ma naturę, która jest czymś specyficznym. Teraz mówię dla przykładu o kwadracie. Jeśli mam z jednej strony kwadratowość i pewną ilość cech, to eksplikuję to w definicji, że to jest równoległobok, prostokątny równoboczny. Ten moment równoboczności spełnia tę samą funkcję, co kwadratowość w kwadracie. Jest to moment natury. Po stronie zaś cech są pewne momenty nawarstwiania cech. Jeśli mówię o rodzaju, to mówię o coraz głębszych warstwach zawartych w naturze przedmiotu, nie odwołując się do cech. Dostaję coraz wyższe

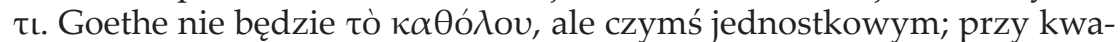

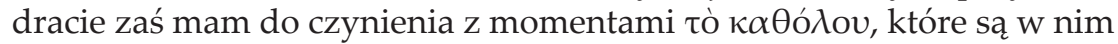
ogólne. Definiując kwadrat, podałem wpierw tò $\gamma \varepsilon ́ v$ os, a potem inne

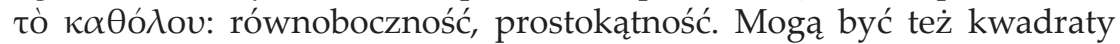
o cechach przypadkowych, na przykład relatywnych (na przykład jeden

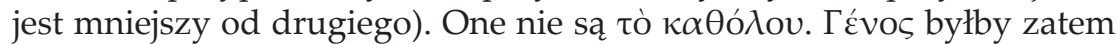

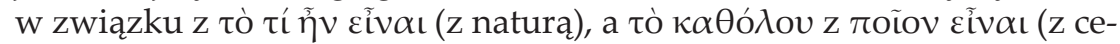
chami). Nie twierdzę wcale, że to jest intencja Arystotelesa.

Pan doktor Swieżawski: $\Sigma v \mu \beta \varepsilon \beta \eta \kappa o ́ \tau \alpha$ (accidentia) dzielą się na accidens commune i proprium ${ }^{45}$. Cecha przypadkowa to byłoby accidens proprium.

Pan profesor [Ingarden]: Nie należy mieszać dwóch przeciwstawień: 1) cechy ogólne i szczegółowe przysługujące jednemu indywiduum;

\footnotetext{
${ }^{42}$ Aristoteles' Metaphysik, 196, przyp. 10.

43 Auguste Mansion, „Bulletin de littérature aristotélique”, Revue Néo-Scolastique de Philosophie, A. 17, (1928), 95, przyp. 1.

${ }^{44}$ Werner Jaeger, Aristoteles. Grundlegung einer Geschichte seiner Entwicklung (Berlin: Weidmannsche Buchhandlung, 1923), 45.

${ }_{45}$ Mariano Fernandez Garcia, Lexicon scholasticum philosophico-theologicum in quo termini, definitiones et effata seu axiomaticae propositiones philosophiam ac theologiam spectantes a B. Ioanne Duns Scoto doctore subtili atque Mariano O. F. M. exponuntur, declarantur, Collegium S. Bonaventurae, Ad Claras Aquas (1910), 569-570.
} 
i 2) cechy istotne i przypadkowe. Accidentia mają szeroki zakres. To toĩov

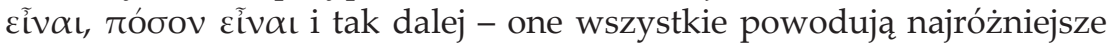
wypadki cech. Jakie jest ich nadrzędne pojęcie nie obejmujące tego $\tau$ ?

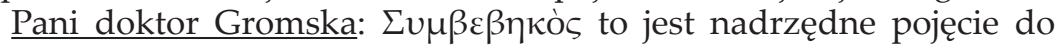

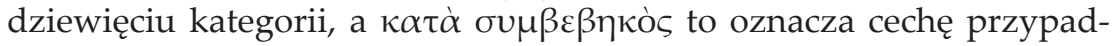
kową.

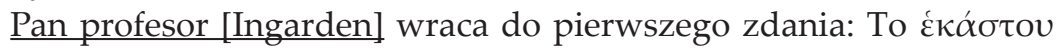
jest dla mnie ważne. Nie należy żadnego z tych trzech znaczeń rozumieć

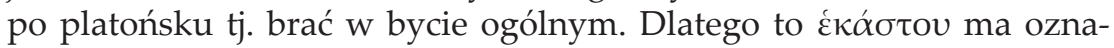
czać, że to w poszczególnych indywiduach da się in concretione znaleźć. Jeśli mam przedmiot czerwony, to chodzi o tę tutaj czerwoność, a nie

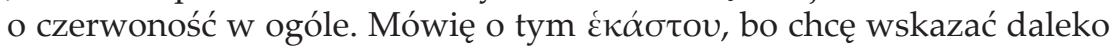
idące konsekwencje wstawienia tego słowa, a to: 1) przeciwstawienie się platonizmowi, a dalej 2) czy formalna ontologia obejmuje wszystko, czy idzie tu o rozpiętość pojęcia oủoía w stosunku do bytu. Dalej idąc, do

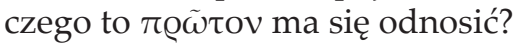

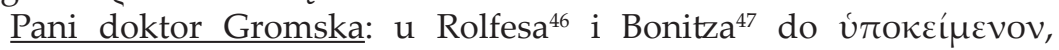

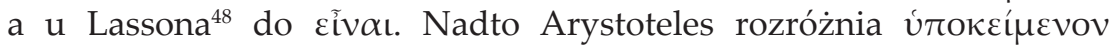

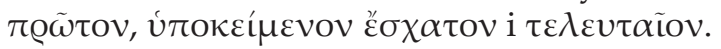

Pan doktor Swieżawski: Według Tomasza idzie tu o substantia pri$m a^{49}$.

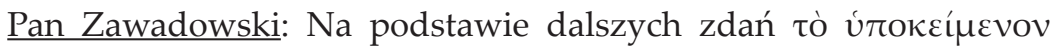
$\pi \varrho \tilde{\omega} \tau o v$ rozpada się na trzy znaczenia, więc dotyczy nie tylko materii

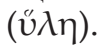

Protokół XI: posiedzenie 10 marca 1938 roku [protokołował Stefan Swieżawski]

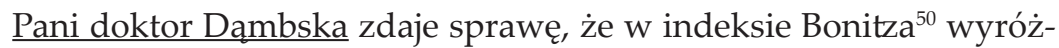

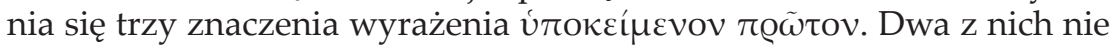

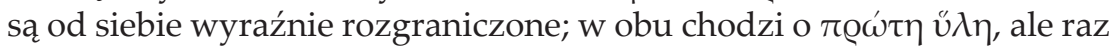
jako pierwsza materia w sensie zupełnie nieuformowanej ú $\lambda \eta$, drugi raz jako relatywnie pierwsza (scil. w stosunku do jakiejś formy). Trzecie zna-

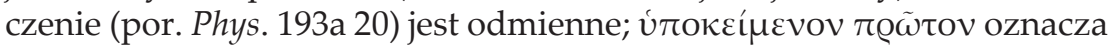
tu naturę jako materię będącą pierwszym przedmiotem rzeczy mających same w sobie i dzięki sobie samym przyczynę ruchu i zmiany. Jest to coś w rodzaju genus proximum.

\footnotetext{
46 Aristoteles' Metaphysik, 132.

47 Aristoteles, Metaphysik, übers. von H. Bonitz, 129.

48 Aristoteles, Metaphysik, übers. von A. Lasson, 95.

49 Sancti Thomae Aquinatis, 382.

${ }^{50}$ Aristotelis Metaphysica, 622.
} 
W rezultacie dyskusji między panem profesorem [Ingardenem] a panią doktor Dąmbską ustaliło się, że zacytowane miejsce z Fizyki ograni-

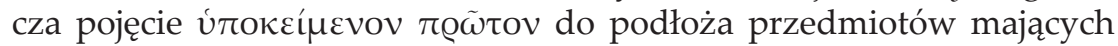
same w sobie źródło ruchu; wobec tego nie pokrywa się to znaczenie z pojęciem najbliższego rodzaju. W ogóle występujące w tym kontekście znaczenie tego terminu nie jest dostatecznie zrozumiałe i należałoby dla lepszego jego zrozumienia przestudiować cały odpowiedni ustęp z Fizy-

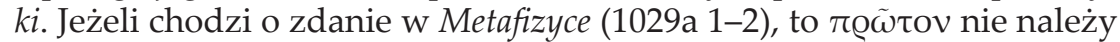

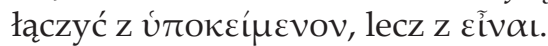

Pani Korczyńska tłumaczy dalej (od 1029a 2) i łącznie z uwagami pana profesora ustala się następujący tekst:

W pewien sposób nazywa się [podłoże] materią w inny sposób forma, a w trzeci tym, co się z obu składa. Nazywam zaś materią coś takiego jak spiż, formą - kształt postaci, a tym, co z obu złożone - posąg.

Pan profesor [Ingarden] stawia pytanie, dlaczego wymienia się

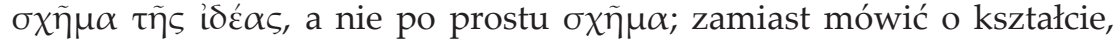
dodaje się „kształt postaci” (zjawiska, wyglądu).

Pan Zieliński sądzi, że wyraz $\sigma \chi \tilde{\eta} \mu \alpha$ jest wieloznaczny i $\tau \tilde{\eta} \varsigma$ i $\delta \dot{\varepsilon} \alpha \varsigma$ ma go bliżej określić, wykluczając inne znaczenie poza znaczeniem "kontury ciała" (scil. przedstawionego w posagu).

Wątpliwość pana Zielińskiego, czy materia, forma i złożone nie są równorzędnymi wyliczeniami znaczeń wyrazu oủ ${ }^{\prime} \alpha$ nawiązującymi do znaczenia jako útoké́ $\mu \varepsilon v o v$ występującego w poprzednim zdaniu upada. Pan profesor [Ingarden] podkreśla że toเoṽ̃ov (1029a 2) musi się odnosić do poprzedniego zdania, a pani doktor Gromska wyjaśnia, że

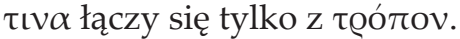

W związku z przetłumaczonymi zdaniami pan profesor [Ingarden] przypomina, że Arystoteles rozróżnił cztery znaczenia, w jakich uży-

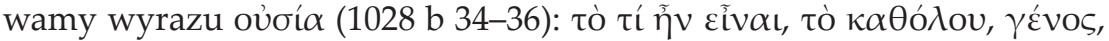

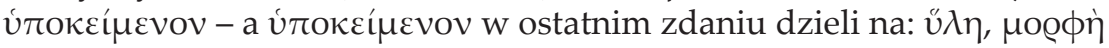

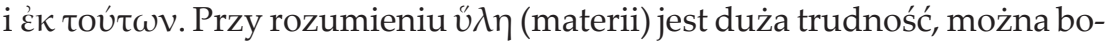
wiem materię pojmować bądź jako konkretny materiał (kawałki drzewa, spiżu itp.), ale wtedy trzeba w tej materii wyróżnić znów materię i formę, i tak w nieskończoność, bądź traktować trzeba materię jako abstrakt wysokiego rzędu, jako przedmiot niesamoistny, nie istniejący rzeczywi-

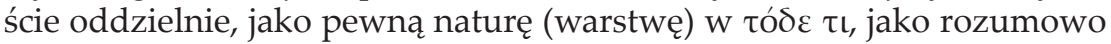
wyabstrahowany przedmiot obdarzony w każdym wypadku innymi cechami, które mu przypisujemy. Ale ta druga interpretacja nie jest zgodna z Arystotelesem. Podobnie i pojęcie $\mu$ ooфì nie jest jasne. $W$ naszym

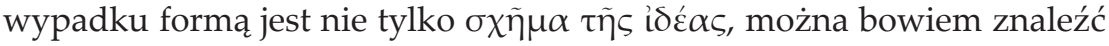
posągu formy niebędące jego postacią (na przykład miękkość przedstawionego ciała ludzkiego dająca się uchwycić w danej rzeźbie). 
Pani doktor Dambska sądzi, iż całe omawiane zdanie ma charakter przykładowy i że kształt posągu wymieniony jest jako jedna $\mathrm{z}$ wielu dających się wyróżnić form.

Pan Jaworski tłumaczy dalej (od 1029a 5).

Po dyskusji ustala się następujący tekst tłumaczenia:

Przeto, jeśli forma jest pierwotniejsza od materii i we właściwym sensie bytem, to będzie pierwotniejsza z tego samego powodu i od złożonego. Teraz więc powiedziało się $\mathrm{w}$ zarysie, czym jest oủoí $\alpha$, że nie tym, co się orzeka o czymś innym, ale o czym orzeka się [wszystko] inne. Ale tym nie można się zadowolić, bowiem to nie jest dostateczne, gdyż to określenie samo jest niejasne i jeszcze materia stałaby się oủoía.

Zaznaczono, że domyślne w ostatnim ustępie „orzeka się" można też zastąpić przez "takoż” (interpretacja przedmiotowa, jak na przykład u Lassona ${ }^{51}$ ). Inna wersja, wedle której toũ (1029a 6) zastępuje się przez тó, nie daje się utrzymać, gdyż płynące z niej konsekwencje nie dają się zupełnie uzgodnić z całością nauki Arystotelesa.

Pan profesor [Ingarden] zapytuje, co w ostatnim zdaniu jest dla Arystotelesa niejasne i niewystarczające?

Po dyskusji, w której zabrali głos pan profesor [Ingarden], pan doktor Bednarowski, pani doktor Dąmbska i pan Zieliński, ustala się, że ze zdań na początku rozdziału trzeciego wynika, że oủoí $\alpha$ może być też

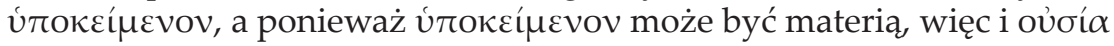

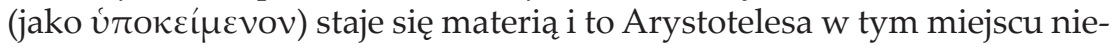
pokoi.

Pan profesor [Ingarden] zwraca uwagę na zdanie 1029a 5-7 i podkreśla, że zdanie to zaczyna się od $\varepsilon i$, tak jakby to było zdanie wtrącone, przytoczone: „jeżeli mówi się, że...", referujące opinię platońską. W zda-

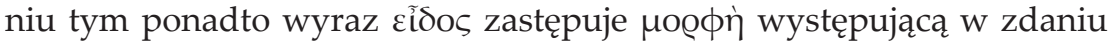
poprzednim. Wygląda tak, jakby cała pierwsza część trzeciego rozdziału była wprowadzeniem przez Arystotelesa w kursujące opinie, w możliwe stanowiska, a nie wykładem jego własnej koncepcji.

Pan Jaworski przytacza zdanie o podobnej treści w księdze M (Metafizyki), gdzie, zdaniem Arystotelesa, we właściwym sensie oủoí $\alpha$ jest rodzaj, jak gatunek, i rzeczy ogólne, jak szczegółowe.

Pani doktor Gromska przypomina, że wedle Jaegera ${ }^{52}$ proces oddalania się Arystotelesa od Platona trwa bardzo długo, że pojęcie عĩ்o jest bliskie idei platońskiej, choć jest pojęciem wyraźnie arystotelesowskim. Dla wyjaśnienia występującego w przytoczonym zdaniu terminu

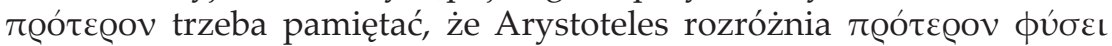

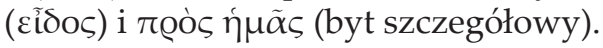

51 Aristoteles, Metaphysik, übers. von A. Lasson, 95.

52 Jaeger, Aristoteles, 407-408. 
Pan profesor [Ingarden] zastanawia się dalej nad pojęciem $\pi$ @ó $\varepsilon \varrho o v$ i twierdzi, że omawiane zdanie byłoby zgodne z całokształtem doktryny

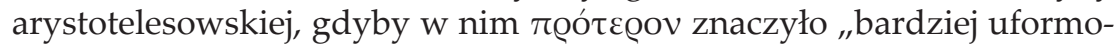
wany, doskonalszy" i wtedy można się zgodzić na to, że sam Arystoteles żywi przekonanie, jakoby forma była doskonalsza od materii. Jeżeli na-

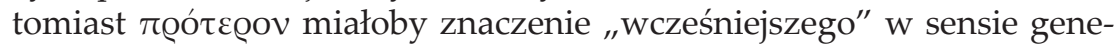
tycznym, czasowym, to zdanie oznaczane byłoby wyraźnie platońskie. Są pewne kłopoty z drugą częścią przetłumaczonego zdania: o ile eĩ̇o jest $\pi$ ¡ó $\varepsilon$ @ov w stosunku do złożonego?

Do następnego posiedzenia należy przerobić tekst do 1029a 34.

Protokół XII: posiedzenie 17 marca 1938 roku [protokołował Bazyli Rudko]

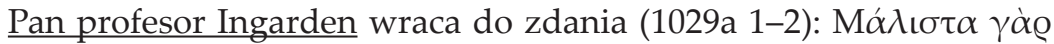

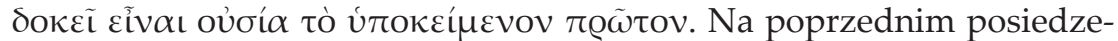
niu ustalono że $\pi \varrho \tilde{\omega} \tau o v$ należy łączyć z eĩv $\alpha \iota$ i tłumaczyć je jako „przede wszystkim". Pan profesor skłania się w tej chwili do tego poglądu, iż ze względu na użyty w przytoczonym zdaniu wyraz $\mu \alpha ́ \alpha \iota \sigma \tau \alpha$ oraz z uwagi

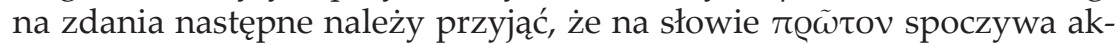

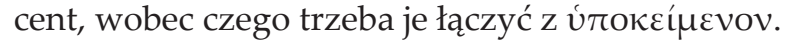

Pan Jaworski tłumaczy od 1029a 10.

Uwagi pani doktor Gromskiej oraz pana profesora pozwoliły ustalić tekst tłumaczenia następująco:

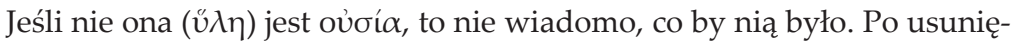
ciu tych innych rzeczy, nie wydaje się, jakoby coś pozostało. Te bowiem inne są stanami czy czynnościami, czy siłami ciał, zaś długość i szerokość, i głębia są pewnego rodzaju wielkościami, ale nie oủoíaı, albowiem to, co wielkie, nie jest oủ $\sigma i ́ \alpha$.

Pan doktor Swieżawski zwraca uwagę na to, iż w związku z rozróżnieniem stanów, sił, czynności oraz wielkości pojawiły się potem u scholastyków, a dalej u Leibniza, pewne koncepcje. To $\mu \tilde{\eta} \kappa o \varsigma$ oraz dwie drugie cechy są jakoś bardziej związane z materią niż inne cechy.

Pan profesor Ingarden wyjaśnia, że wyrażenie $\tau \dot{\alpha} \alpha \ddot{\alpha} \lambda \lambda \alpha$ (1029a 12) oznacza to wszystko, co należy do dziewięciu kategorii z wyjątkiem oủoía.

Pani Korczyńska tłumaczy od 1029a 15:

Ale raczej to jest oủoí $\alpha$, czemu tamte przysługują. Po odrzuceniu bowiem długości i szerokości, i głębi widzimy, że nic nie pozostaje z wyjątkiem tego, co przez tamte zostaje określone, jeśli coś takiego jest. Przy takim rozważaniu jedyną oủoía musi się wydać z konieczności materia. 


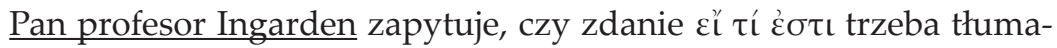
czyć jako zdanie wtrącone: ,jeśli coś takiego jest”. Taki sposób tłumaczenia zakłada wielką ostrożność stanowiska. U Rolfesa czytamy w odpowiednim miejscu ,"...] so sehen wir nichts übrig bleiben, als das, was etwa durch sie bestimmt wird"53. Tutaj nie ma tego zastrzeżenia, które uwydatniło się w tłumaczeniu pani Korczyńskiej.

Pani doktor Gromska zwraca uwagę na różnicę pojedynczych tek-

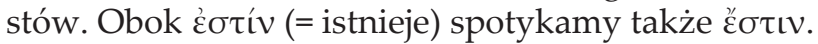

Pan profesor Ajdukiewicz jest zdania, że dla wyjaśnienia omawianego miejsca dobrze byłoby wiedzieć o zapatrywania Arystotelesa na kwestię próżni. Można by omawiane zdanie rozumieć: w wypadku, jeżeli coś jest przez nie (rozmiary przestrzenne) ograniczone, a nie w wypadkach próżni. Istnienie materii byłoby podane w wątpliwość, gdyby rozumieć: jeśli coś takiego istnieje jak materia.

Pan profesor Ingarden sądzi, że zdanie następujące (1029a 19) nasu-

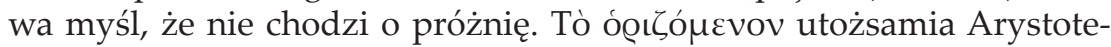

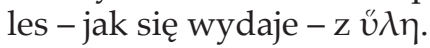

Pan Zawadowski: W Fizyce $\Delta$ jest mowa o próżni. Zagadnienie przestrzeni u Arystotelesa rozpada się na zagadnienie miejsca i zagadnienie próżni. Omawiane miejsce z Metafizyki przemawia raczej za tym, iż $\mu \tilde{\eta} \kappa o \zeta$ itd. odnosi się do ciał $(\sigma \omega ́ \mu \alpha \tau \alpha)$.

Pani doktor Dambska tłumaczy od 1029a 20.

Tekst tłumaczenia, po uwzględnieniu uwag pana profesora, pani doktor Gromskiej i pana doktora Swieżawskiego, ustalono jak następuje:

Rozumiem zaś przez materię to, co samo przez się nie jest uważane ani za coś, ani za wielkość, ani za żadne inne z tych, którymi określa się byt. Istnieje bowiem coś, o którym (czym) orzeka się każde z tych, któremu jednak inny rodzaj bytu przysługuje i czego byt jest inny, jak każdej z kategorii. Wszystkie bowiem inne orzekane są oưoí $\alpha$, ona zaś sama o materii. Tak, iż to, co ostatnie samo przez się istnieje, nie jest ani coś, ani ilościowo określone, ani coś inne. Ale i zaprzeczeniami tych rzeczy nie jest. Albowiem i te zaprzeczenia przysługują tylko jako przysługujące. Na podstawie tego jedynie materia jest z konieczności oủoía dla tych, którzy tak widzą.

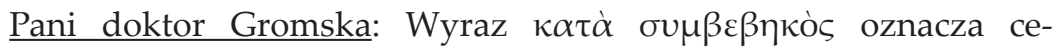
chę przypadkowa, to znaczy taka, która może przedmiot posiadać lub nie.

Pani doktor Dạmbska zwraca uwagę na to, iż tym, co się o ú $\lambda \eta$

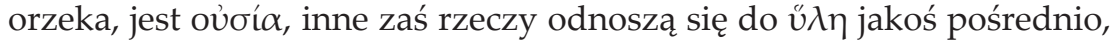

53 Aristoteles' Metaphysik, 133. 
a wprost się odnoszą do oủoía. W tym wypadku powiedziałoby się, że

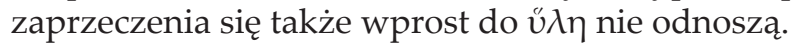

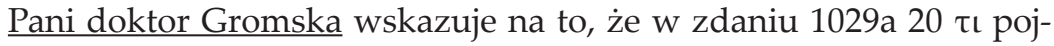
muje się jakościowo. Przy takim rozumieniu uwalniamy się od trudności interpretacyjnych $\mathrm{w}$ tym zdaniu.

Pan profesor Ingarden zwraca uwagę, że idąc za świętym Toma-

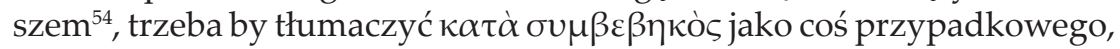
a nie coś pochodnego, ani jako coś, co przysługuje jako przysługujące.

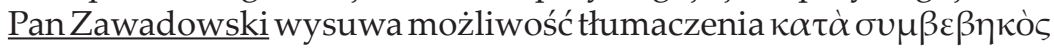
jako „coś przypadkowego". Nie należałoby tego rozumieć jako dowolności; chodziłoby tutaj o cechy, które mogą przysługiwać lub nie. W tym

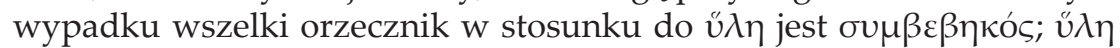
jest czymś niezmiennym, co pozostaje tym samym przy zmieniających

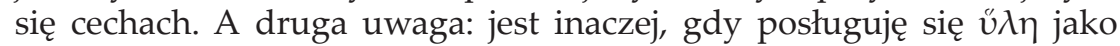
pojęciem do określenia przedmiotu, a inaczej, gdy mówimy o ú $\lambda \eta$ jako o pewnym przedmiocie.

Pan profesor Ingarden sądzi, że rozróżnienie tych dwóch pięter nie jest potrzebne. Arystoteles błądzi z tą chwilą gdy pragnie określić $u ́ \lambda \eta$, coś nieokreślonego.

Nasuwa się tutaj zagadnienie związane z kategoriami. Jeżeli mamy jakieś $\tau o ́ \delta \varepsilon \tau \iota$, to powstaje pytanie, czy ono ma być określane przez jedną dwie kategorie, czy może musi być określone w dziewięciu aspektach. W tym ostatnim wypadku nie można już mówić o tym, że kategorie są przypadkowe, tylko że przypadkowe są wypadki kategorii. Jeśli te wszystkie aspekty są konieczne, to nie wiadomo, co przez kategorie rozumieć: czy tych dziewięć aspektów, czy te wypadki (sposoby).

Pan doktor Bednarowski zwraca uwagę, że wszystkie te rzeczy ( $\tau \iota, \pi$ Toเóv) można brać jako konkreta, a zaprzeczenie może być zaprzeczeniem tego określonego $\tau \mathrm{l}, \mathrm{z}$ tym że przysługuje mu jakieś inne $\tau \mathrm{t}$.

Pan profesor Ingarden wskazuje na pożyteczność odróżnienia między strukturami tego „,coś” a poszczególnymi wypadkami. I sama struk-

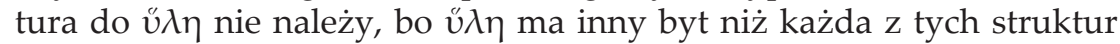
i każdy z wypadków.

Protokół XIII: posiedzenie 28 kwietnia 1938 roku [protokołowała Daniela Gromska]

Pan doktor Swieżawski w związku z tekstem księgi Z 1029a (od początku do 27) czyta przekład komentarza Tomasza do tego miejsca (Tomasz, 1287-1290 włącznie) $)^{55}$. Omówienie tego komentarza odłożono

54 Sancti Thomae Aquinatis, 380.

55 Tamże, 384-385. 
na następny raz. Przystąpiono do przekładu zdania z 1029b: غ̇ंદદi $\delta$ ' $\dot{\varepsilon} v$

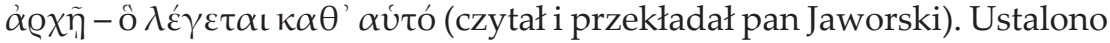
następujący przekład:

Skoro więc na początku rozróżniliśmy, na ile sposobów określamy oủoí $\alpha$ i jeden z nich wydawał się być bycie tym coś, czym się było, należy go rozważyć. I najpierw powiemy kilka rzeczy o tym w sposób logiczny, że dla każdego przedmiotu to bycie tym coś, czym się było, jest tym, co się o nim orzeka jako samym przez się.

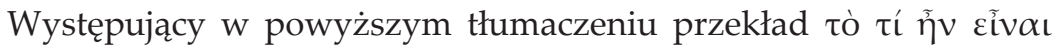
jako „bycie tym coś, czym się było" pochodzi od pana profesora Ingardena(?), który, uzasadniając swoją propozycję, wygłosił następujące twierdzenia:

1) Przekładanie tego zwrotu przy pomocy jednego wyrazu, na przykład essentia, istota itp., jest niewskazane, bo taki przekład zawiera interpretację.

2) Zaproponowany przekład ma tę zaletę, że nasuwa możliwość

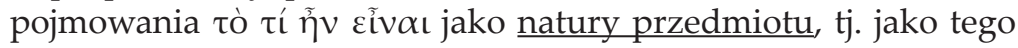
$\mathrm{w}$ przedmiocie zmieniającym się $\mathrm{w}$ czasie, co przez cały ciąg istnienia przedmiotu trwale $\mathrm{w}$ niezmienionej postaci mu przysługuje. To, czym przedmiot jest teraz i czym zarazem był przed tym, odkąd istniał.

Tłumaczenie pana profesora Ingardena wychodzi z założenia, że czas przeszły słówka ñv występującego w tłumaczonym zwrocie jest dla sensu tego zwrotu istotny.

W związku z tą sprawą pani doktor Gromska referuje dwa poglą-

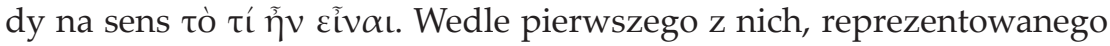

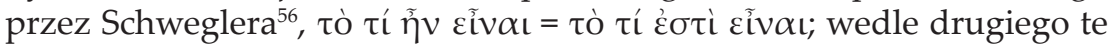

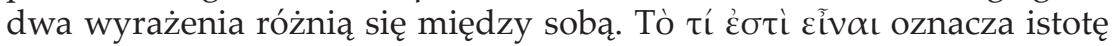

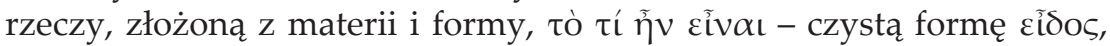
która wyprzedza nie tylko pojęciowo, lecz i czasowo przedmiot złożony z materii i formy; stąd imperfectum.

Profesor Ingarden uważa tę drugą interpretację za platonizującą.

\section{Protokół XIV: posiedzenie 5 maja 1938 roku}

[protokołował Władysław Jaworski]

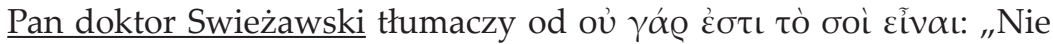
jest bowiem bycie tobą byciem wykształconym. Bo nie sam przez się jesteś wykształcony, jednak tym, czym bywszy, jesteś, jesteś sam przez się".

56 Albert Schwegler, Die Metaphysik des Aristoteles. Grundtext, Übersetzung und Commentar nebst erläuternden Abhandlungen, Bd. 4: Des Commentars zweite Hälfte, L. Fr. Fues (Tübingen 1848), 55-56. 
Pan profesor [Ingarden] zapytuje, czy jakieś z tłumaczeń uwzględ-

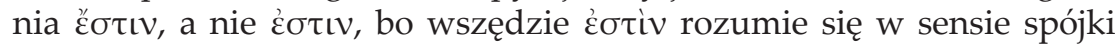

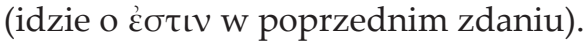

Pani doktor Gromska zwraca uwagę na trudność w egzystencjalnym rozumieniu odnośnego miejsca.

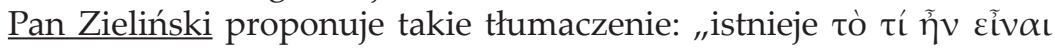
dla tych i tylko dla tych przedmiotów, które orzeka się same przez się".

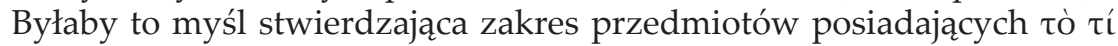
ก̃v عĩvat.

Pan profesor [Ingarden]: Pan Zieliński proponuje więc tak: „istnie-

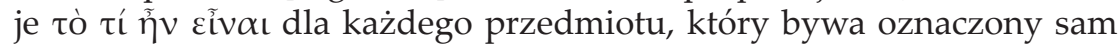
w sobie". Idea byłaby tego rodzaju: Założywszy, że są jakieś przedmioty $\alpha$ oraz jakieś przedmioty $\beta$, i założywszy, że każdą rzecz można nazwać albo właściwie, albo dowolnie (adekwatnie lub nieadekwatnie), dochodzimy do tego, że, nazywając adekwatnie przedmioty $\alpha$, nazywamy je $\mathrm{w}$ momencie ich natury, $\mathrm{w}$ ich swoistości, podczas gdy przedmioty $\beta$ nie dadzą się już tak nazwać adekwatnie w tym momencie ich natury, lecz tylko pod aspektem ich stosunku do czegoś, do ich jakiejś cechy (na przykład nazywając kogoś „,rudy”). Przy tej więc interpretacji tylko ade-

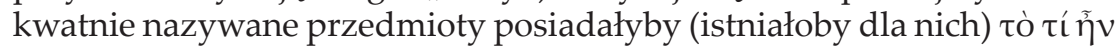
عĩvaı. Tylko czy cała ta sprawa da się gramatycznie naciągnąć? Można by zatem to zdanie czytać $\mathrm{w}$ dwa sposoby. W jednym jest wyłuszczenie

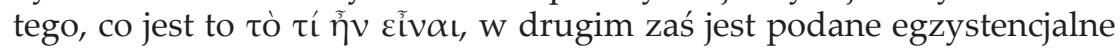

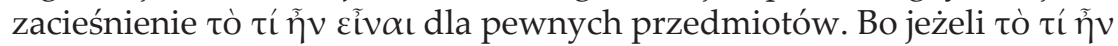

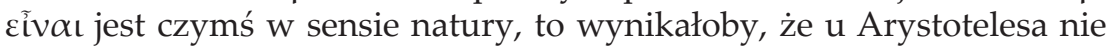
wszelkie przedmioty mają natury.

Pan doktor Bednarowski: Dalszy tekst wskazuje, że interpretacja

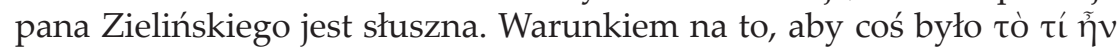

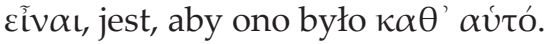

Pan profesor [Ingarden] zawiesza całą tę sprawę. Idąc dalej, dlaczego tu jest to $\gamma \alpha \dot{Q}$ ?

Pan doktor Swieżawski uważa, że ono służy do uzasadnienia na przykładzie z owym byciem tobą.

Pan profesor [Ingarden]: To bycie tobą czytane w pierwszy sposób

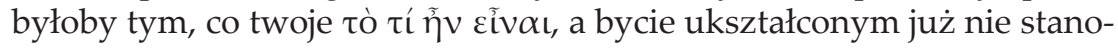

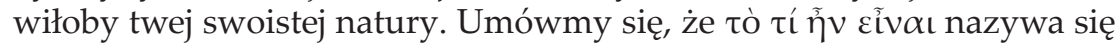
swoista istota. Takie tłumaczenie przemawiałoby za pierwszym sposobem czytania.

Pan doktor Swieżawski cytuje ze świętego Tomasza: „To bowiem, co orzeka sięper accidens, nie przynależy do odpowiedzi na pytanie quidest" ${ }^{\prime \prime 7}$.

57 Sancti Thomae Aquinatis, 391. 
Byłoby tu zatem pewne podobieństwo z Essentiale Fragen ${ }^{58}$ co do pytania quid est.

Pan doktor Swieżawski tłumaczy dalej: „Ale nie wszystko tak” i są-

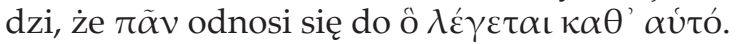

Pani doktor Gromska: $\pi \tilde{\alpha} v$ nie znaczy tu "wszystko", ale "cały”.

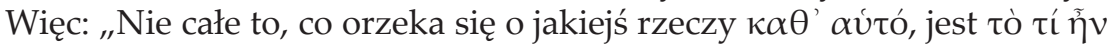

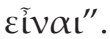

Pan doktor Swieżawski tłumaczy dalej:

Bowiem w ten sposób nie orzeka się $\kappa \alpha \theta^{\prime}$ aútò jak o powierzchni, że jest biała, bo bycie białą powierzchnią nie jest byciem białym. Ale o tym nie orzeka się, co złożone z obu, a to o byciu białej powierzchni.

Pan profesor [Ingarden]: Ale to, co złożone z białości oraz z po-

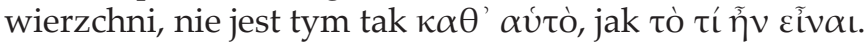

Pan profesor eksplikuje to na przykładzie: Kwadrat jest to równo-

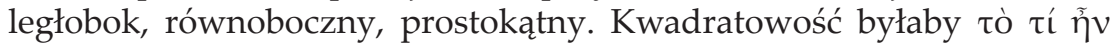

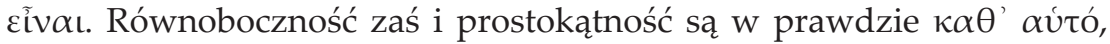

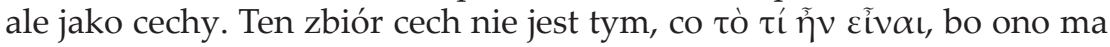
strukturę natury przedmiotu, strukturę jego konstytuowania.

Pan doktor Swieżawski: Czy dla każdego przedmiotu mającego tò

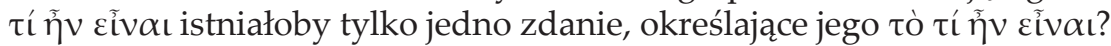

Pan profesor [Ingarden]: Matematycznie wyznaczając jednoznacznie jakiś przedmiot, dysponujemy różnymi dopuszczalnymi określeniami. Jednak ze stanowiska bytowo-kategorialnego, gdy chodzi o postać jakiegoś przedmiotu, istnieje tylko jedno określenie momentu jego na-

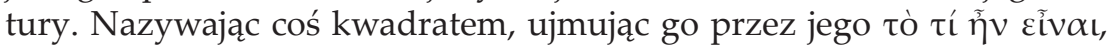
określając zaś go przy pomocy cech, dobieram takie momenty, które są równoważne tej „kwadratowości”. Tutaj owo samo bycie powierzchnią

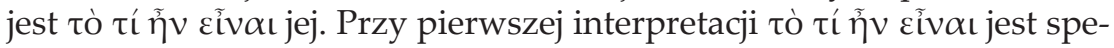
cjalnym wypadkiem bycia $\kappa \alpha \theta^{\prime} \alpha u ̛ \tau o ́$. I tu powierzchnia jest sama w sobie powierzchnią inaczej, niż jest sama w sobie białą. Istniałyby zatem różne $\kappa \alpha \theta^{\prime}$ ' $\alpha$ útò z uwagi na ucechowanie przedmiotu, ale to już byłaby

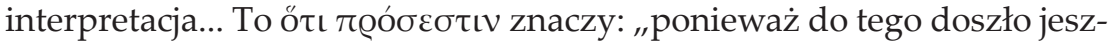
cze coś innego".

Dalej od $\dot{\varepsilon} v \tilde{u}$ tłumaczy pan Zieliński: „W którym więc pojęciu nie tkwi ono samo dla mówiącego je, to to jest pojęciem bycia, czym bywszy, jest się każdej rzeczy".

Pan doktor Swieżawski proponuje na $\lambda o ́ \gamma o \varsigma$ - „wyrażenie”. Jednak utrzymuje się $\lambda o ́ \gamma o \varsigma$ - „pojęcie” po dyskusji.

58 Roman Ingarden, „Essentiale Fragen. Ein Beitrag zum Problem des Wesens”, Jahrbuch für Philosophie und Phänomenologische Forschung, Bd. 7 (1925): 125-304. 
Pan profesor [Ingarden]: $\mathrm{W}$ czego pojęciu to coś samo nie jest zawarte dla mówiącego o tym czymś.

Pani doktor Gromska: Muszą być spełnione dwa warunki na to, aby

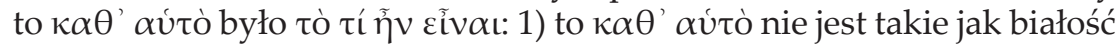
powierzchni i 2) w określeniu nie może występować definiendum $\mathrm{w}$ definiens.

\section{$\underline{\text { Protokół XV: posiedzenie } 19 \text { maja } 1938 \text { roku }}$}

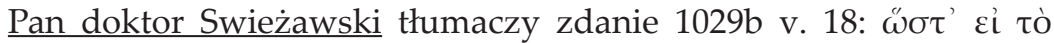

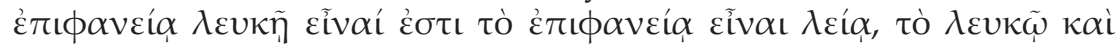

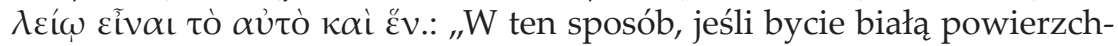
nią jest byciem powierzchnią gładka, to bycie białym i gładkim jest tym samym".

Pan profesor Ingarden ma wątpliwość, czy cì w tym zdaniu tak należy tłumaczyć, jak doktor Swieżawski. Zapytuje, czy można to eỉ tłumaczyć przez "gdyby", ,jeśliby".

Pani doktor Gromska sądzi, że są względy gramatyczne przeciw takiemu tłumaczeniu (nie ma tu ővv), gdyż spójnik "gdyby" implikuje zdanie warunkowe nierzeczywiste, z "gdyby" wynika, że tak nie jest, podczas gdy ,jeżeli" pozostawia dany stan rzeczy w zawieszeniu.

Panu profesorowi [Ingardenowi] wydaje się, że spójnik „,jeżeliby" nadawałby się do tego miejsca dla zaznaczenia możliwości wypadku takiego, że biała i gładka powierzchnia są tym samym.

Pan doktor Swieżawski dopatruje się w tym zdaniu, opierając się na komentarzu Tomasza ${ }^{59}$, tendencji ekstensjonalizmu.

Pani doktor Dambska sądzi, że zdanie to z punktu logicznego jest tautologiczne.

Pani doktor Romahnowa zwraca uwagę na komentarz Rossa ${ }^{60}$. Według Rossa identyfikacja biały = gładki ma podawać tu istotę białości. Kwestią jest tu, na czym polega ta identyfikacja. Ross przypomina, że to odnosi się do poglądów Demokryta.

Pan profesor [Ingarden] sądzi, że zdanie to nabrałoby innego sensu, jeśliby się odnosiło do Demokryta. Nie można rozumieć tego miejsca ekstensjonalistycznie.

Pan doktor Swieżawski na poparcie swego twierdzenia (ekstensjonalizm) przytacza z komentarza świętego Tomasza odpowiednie miejsce $(1314)^{61}$ :

59 Sancti Thomae Aquinatis, 391.

${ }^{60}$ Aristotle's Metaphysics, 168.

${ }^{61}$ Sancti Thomae Aquinatis, 391. 
Si albedo pertinet at quod quid est superficiei, pari ratione et levitas. Quae autem uni et eidem sunt eadem [sibiinvicem sunt eadem]. Quare si superficiei album esse est superficiei esse semper, idest si semper et universaliter hoc verum est quod quidditas propriae passionis sit idem cum quidditate proprii subiecti, sequitur quod albo esse et levi esse, sit idem et unum, idest quod quidditas albedinis et levitas sit una et eadem. Hoc autem patet falsum esse.

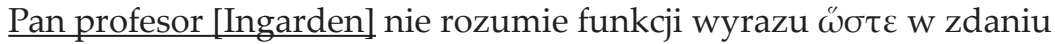
interpretowanym. Szuka więc w poprzedzających zdaniach uzasadnie-

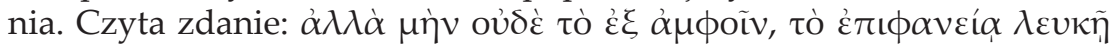
[عĩvol] - „Lecz zaiste to, co jest złożone z powierzchni i białości, nie jest

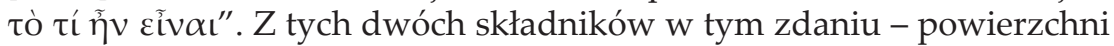
i białości - powierzchnia jest ukonstytuowana przez powierzchniowość

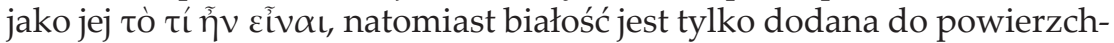

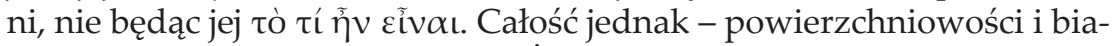

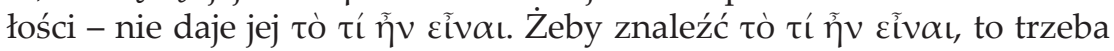
znaleźć coś, co nie jest powierzchnią ale ją ukonstytuowuje. Powyższe zdanie jednak nie jest również z $\omega ّ \sigma \tau \varepsilon$.

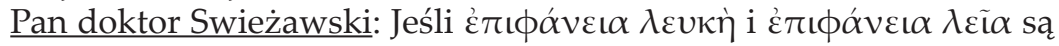

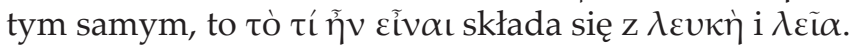

Pan profesor [Ingarden]: Gdybyśmy to zdanie rozumieli w sensie demokrytowskim, wówczas byłoby jasne. Największe trudności nastręcza tu $\omega \sigma \tau \varepsilon$.

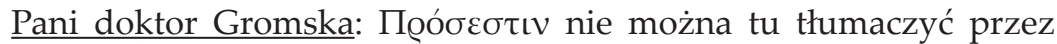

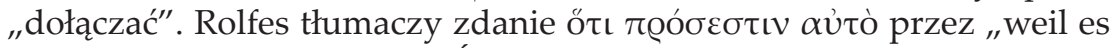
ihr (der Fläche) inhäriert” ${ }^{\prime \prime 2}$. Święty Tomasz tłumaczy przez „inesse”63,

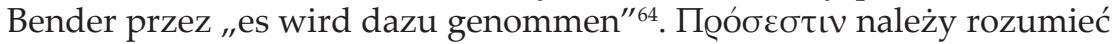

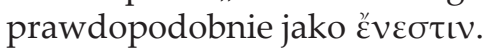

Pan profesor [Ingarden] cytuje uwagę Rolfesa do zdania interpretowanego (uwaga 18) „Man sagt von der Fläche, daß sie an sich weiß ist" 65 . Powierzchnia jest czymś „an sich” przez powierzchniowość. Ciało jest białe pochodnie, powierzchnia zaś jest $\mathrm{w}$ sobie biała, ale nie jest $\mathrm{w}$ ten

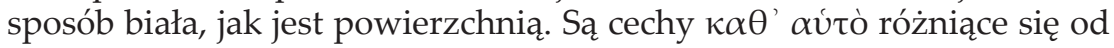

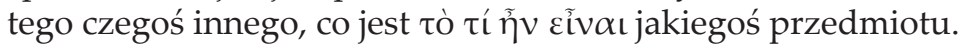

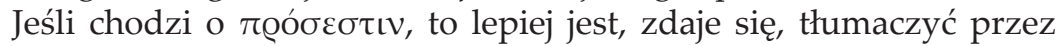
"dołącza się".

Pan doktor Swieżawski: W tym zdaniu zaczynającym się od $\omega \sigma \tau \varepsilon$

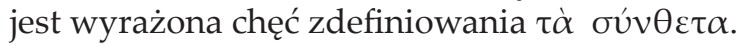

Pan doktor Swieżawski tłumaczy dalej:

62 Aristoteles' Metaphysik, 134.

63 Sancti Thomae Aquinatis, 388.

${ }^{64}$ Die Metaphysik des Aristoteles, übers. von H. Bender, 169.

${ }^{65}$ Aristoteles' Metaphysik, 197, przyp. 18. 
Skoro jednak istnieją byty złożone i w innych kategoriach (istnieje podłoże dla każdej z kategorii, np. dla jakości, ilości, czasu, miejsca i ruchu),

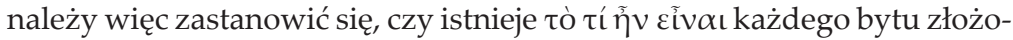

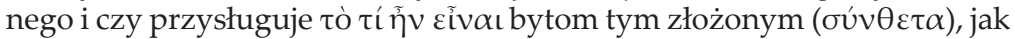

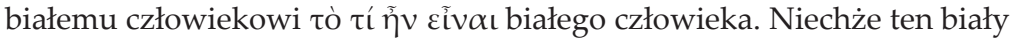

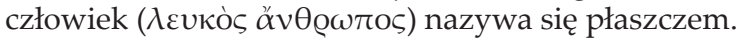

Pan doktor Swieżawski w ten sposób interpretuje swoje tłumacze-

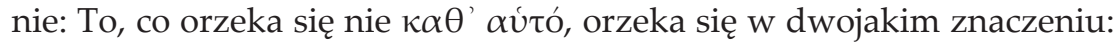

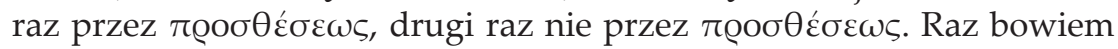
mówi się, że dokłada się wyraz definiowany do drugiego, drugi: inne wyrażenie dodaje się do tego drugiego w przykładzie, gdy płaszcz ma oznaczać białego człowieka.

Pan profesor Ingarden sądzi, że zachodzą tu dwa wypadki nie $\kappa \alpha \theta$ aútó: 1) Po pierwsze: coś nie jest samo przez się, bo jest z czegoś (jakieś ens entis); 2) Po drugie: coś nie jest samo w sobie, bo się uwzględnia cechy tego przedmiotu.

Pani doktor Gromska tłumaczy dalej, przy czym tłumaczenie jej zbliża się do tłumaczenia Rolfesa tego miejsca: „Oder wird vielmehr das «nicht an sich» zweimal ausgesagt und ist es das eine davon durch Hinzufügung, das andere nicht?"66. Greckie ì w tym zdaniu tłumaczy pani doktor Gromska przez „otóż”. To wyrażenie bowiem wyjaśnia dwa znaczenia tego, co nie należy do samego siebie.

Protokół XVI: posiedzenie 23 czerwca 1938 roku [protokołował Bolesław Zieliński]

Pan Zawadowski tłumaczy zdanie 1030a. Wyłania się dylemat, czy

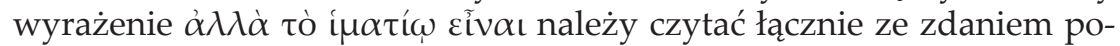
przednim, czy ze zdaniem następnym.

Pan profesor Ingarden zauważa, że dziwną konsekwencją poprzednich wywodów Arystotelesa byłoby postawienie pytania: Czy coś w ogóle takiego jak ",to, czym się bywszy, jest” istnieje?

Na wniosek pana Zawadowskiego przyjęto skrótowe tłumaczenie

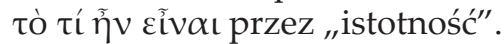

Pan doktor Swieżawski cytuje przekład świętego Tomasza. Okazuje się, że święty Tomasz łączy omawiane wrażenie ze zdaniem poprzednim, a ő’ $\alpha$ tłumaczy przez „,czego".

Pozostaje do wyjaśnienia filologiczna strona słówka ó@ $\alpha$.

W wyniku dyskusji nad wyżej przedstawionym dylematem pan profesor Ingarden zawiesza decyzję przed dalszym tłumaczeniem.

66 Tamże, 135. 


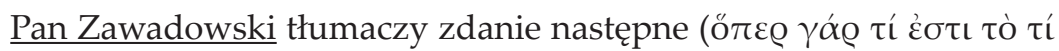

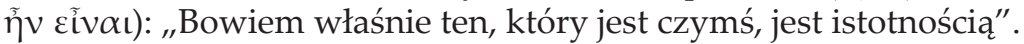

Rolfes $^{67}$ tłumaczy odwrotnie: dla niego istotność jest podmiotem tego zdania.

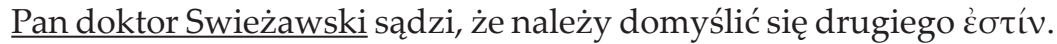

Pan profesor Ingarden tłumaczy: „Cokolwiek coś jest czymś, jest zarazem to, czym się bywszy, jest".

67 Tamże, s. 135. 